\title{
KISS1R: Hallmarks of an Effective Regulator of the Neuroendocrine Axis
}

\author{
Robert P. Millar ${ }^{a, b}$ Andy V. Babwah ${ }^{c-f}$ \\ ${ }^{a}$ Mammal Research Institute, University of Pretoria, Pretoria, and ${ }^{b}$ Medical Research Council Receptor Biology Unit,

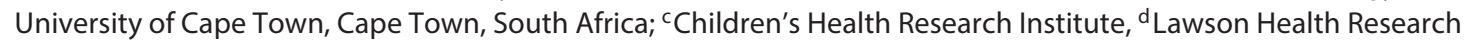 \\ Institute, and Departments of ${ }^{\mathrm{e}}$ Obstetrics and Gynaecology and ${ }^{\mathrm{f}}$ Physiology and Pharmacology, University of \\ Western Ontario, London, Ont., Canada
}

\section{Key Words}

$\mathrm{KISS} 1 \mathrm{R} \cdot \mathrm{Kisspeptin} \cdot \mathrm{Ga}_{\mathrm{q} / 11} \cdot \beta$-Arrestin $\cdot \mathrm{GnRH}$ neuron .

Gonadotrope · Signaling · Desensitization · Internalization

\begin{abstract}
Kisspeptin (KP) is now well recognized as a potent stimulator of gonadotropin-releasing hormone $(\mathrm{GnRH})$ secretion and thereby a major regulator of the neuroendocrine-reproductive axis. KP signals via KISS1R, a G protein-coupled receptor (GPCR) that activates the $\mathrm{G}$ proteins $\mathrm{Ga}_{\mathrm{q} / 11}$. Modulation of the interaction of KP with KISS1R is therefore a potential new therapeutic target for stimulating (in infertility) or inhibiting (in hormone-dependent diseases) the reproductive hormone cascade. Major efforts are underway to target KISS1R in the treatment of sex steroid hormone-dependent disorders and to stimulate endogenous hormonal responses along the neuroendocrine axis as part of in vitro fertilization protocols. The development of analogs modulating KISS1R signaling will be aided by an understanding of the intracellular pathways and dynamics of KISS1R signaling under normal and pathological conditions. This review focuses on KISS1R recruitment of intracellular signaling $\left(\mathrm{Ga}_{\mathrm{q} / 11^{-}}\right.$and $\beta$-arrestin-dependent) pathways that mediate $\mathrm{GnRH}$ secretion and the respective roles of rapid desensitization, internalization, and recycling of resensitized receptors in maintaining an active population of KISS1R at the cell surface to
\end{abstract}

facilitate prolonged KP signaling. Additionally, this review summarizes and discusses the major findings of an array of studies examining the desensitization of KP signaling in man, domestic and laboratory animals. This discussion highlights the major effects of ligand efficacy and concentration and the physiological, developmental, and metabolic status of the organism on KP signaling. Finally, the potential for the utilization of KP and analogs in stimulating and inhibiting the reproductive hormone cascade as an alternative to targeting the downstream $\mathrm{GnRH}$ receptor is discussed.

๑) 2015 S. Karger AG, Basel

\section{Introduction}

Hypothalamic gonadotropin-releasing hormone $(\mathrm{GnRH})$ has long been recognized as the master regulator of the neuroendocrine-reproductive axis. Diminished GnRH secretion or actions can result in congenital hypogonadotropic hypogonadism $(\mathrm{HH})$, a disorder that is characterized by the absence of spontaneous sexual maturation in the presence of low gonadotropins [luteinizing hormone (LH) and follicle-stimulating hormone (FSH)] and sex steroids (estradiol and testosterone) in the absence of anatomical or functional abnormalities of the hypothalamic-pituitary-gonadal axis. $\mathrm{HH}$ results from disruption of the migration of GnRH neurons from the

\section{KARGER 125\%}

(c) 2015 S. Karger AG, Base

0028-3835/15/1013-0193\$39.50/0

E-Mail karger@karger.com

www.karger.com/nen
Dr. Andy V. Babwah

Victoria Research Laboratories, Children's Health Research Institute

800 Commissioners Road East

London, ON N6C 2V5 (Canada)

E-Mail ababwah@uwo.ca 
olfactory placode to the hypothalamus during embryonic development, or from diminished pulsatile GnRH secretion from the established population of hypothalamic $\mathrm{GnRH}$ neurons, presumably due to altered neuronal inputs, or from inactivating mutations in $\mathrm{GnRH}$ or its cognate receptor [1-4].

Our understanding of the molecular regulation of $\mathrm{GnRH}$ secretion in animal models has grown tremendously in the last decade. At the forefront of this advance was the discovery of three neuropeptides: the opioid peptide dynorphin (DYN), the tachykinin peptide neurokinin $\mathrm{B}$ (NKB), and in particular the RF-amide peptide kisspeptin (KP). In goats, sheep, and laboratory rodents, all three peptides are highly coexpressed in a population of neurons in the arcuate nucleus called the KNDy neurons, and it is now well accepted that through their interactions these peptides play a pivotal role in regulating pulsatile GnRH secretion [5-9]. However, in human males, KPexpressing neurons in the infundibular nucleus, a region analogous to the arcuate nucleus of other species, coexpress NKB but surprisingly very little DYN $[9,10]$. In human females, however, there is evidence that the same neurons in the infundibular nucleus express KISS1 [11], DYN [12], and NKB [13]. Thus, while there appear to be species and gender differences in the presence and roles of these peptides, there is a consensus that $\mathrm{KP}$, signaling through its receptor (KISS1R) located on the surface of $\mathrm{GnRH}$ neurons, is a direct trigger of $\mathrm{GnRH}$ secretion in mammals [14-22]. GnRH then regulates the synthesis and secretion patterns of gonadotropins from pituitary gonadotropes through changes in pulse frequency and amplitude [23-26].

While numerous studies have focused on the role of $\mathrm{KP}$ as a potent regulator of $\mathrm{GnRH}$ secretion, few studies have explored the mechanisms by which KISS1R mediates KP signals intracellularly in the GnRH neuron as well as in other cell types. Therefore, this review will focus on KISS1R recruitment of intracellular signaling pathways that mediate GnRH secretion and the dynamics of ligandinduced internalization of KISS1R, degradation, and recycling, as well as desensitization.

\section{KP Signals via KISS1R and $\mathrm{Ga}_{\mathrm{q} / 11}$}

KISS1R, which was first designated as the orphan receptor GPR54, was cloned using a degenerate PCR strategy to identify cDNAs encoding G-protein-coupled receptor (GPCRs) [27]. While the novel receptor shared high sequence identities in the transmembrane regions of galanin receptors, KISS1R failed to bind ${ }^{125}$ I-galanin [27]. In 2001, four independent studies identified KISS1R agonists [28-31]. A study by Clements et al. [28] suggested that the KISS1R cognate ligand is an RF-amide, while the other three studies specifically identified KP as the RFamide [29-31]. In those studies, the authors demonstrated that KP triggered a robust mobilization of intracellular $\mathrm{Ca}^{2+}$ in KISS1R-expressing cells, suggesting that coupling occurred via $G a_{\mathrm{q} / 11}$ with the resulting activation of phospholipase $\mathrm{C}$, hydrolysis of phosphatidylinositol 4,5-bisphosphate (PIP2), and generation of inositol phosphates (IP). Muir et al. [30] and Kotani et al. [29] also demonstrated that KP does not couple KISS1R to $\mathrm{Ga}_{s}$ and that pertussis toxin, an inhibitor of $\mathrm{Ga}_{\mathrm{i} / \mathrm{o}}$, fails to block the mobilization of $\mathrm{Ca}^{2+}[29,30]$.

$\mathrm{Ga}_{\mathrm{q}}$ family members include $\mathrm{Ga}_{\mathrm{q}}, \mathrm{Ga}_{11}, \mathrm{Ga}_{14}$, and $\mathrm{Ga}_{15 / 16}$ [32]. $\mathrm{Ga}_{\mathrm{q}}$ and $\mathrm{Ga}_{11}$ are functionally redundant and widely expressed in the body, including the brain. However, the expression of $\mathrm{Ga}_{14}$, and $\mathrm{Ga}_{15 / 16}$ is restricted to tissues like the kidney and hematopoietic organs, respectively, with almost no detectable expression in the brain [32-34]. Kotani et al. [29] and Wacker et al. [35] demonstrated that KISS1R can also couple to $\mathrm{Ga}_{15 / 16}$ and thereby generate inositol trisphosphate (IP3) which mobilizes intracellular $\mathrm{Ca}^{2+}$. This finding was not surprising given that $\mathrm{Ga}_{15 / 16}$ promiscuously couples a large number of GPCRs to phospholipase C $\beta$ (PLC $\beta$ ) activation and PIP2 hydrolysis $[36,37]$. $\mathrm{Ga}_{14}$ has also been reported to couple some $\mathrm{Ga}_{\mathrm{i}^{-}}$and $\mathrm{Ga}_{\mathrm{s}}$-coupled receptors to PLC $\beta$ activation [38]; however, promiscuous coupling by $\mathrm{Ga}_{14}$ does not appear to be as widespread as that displayed by $\mathrm{Ga}_{15 / 16}$. It is currently unknown whether KISS1R can signal via $\mathrm{Ga}_{14}$. However, from the perspective of this review on KISS1R signaling, coupling to $\mathrm{Ga}_{15 / 16}$ and $\mathrm{Ga}_{14}$ is not relevant as these are not expressed in the hypothalamus [32-34]. Thus, in hypothalamic GnRH neurons, KPbound KISS1R signals via $\mathrm{Ga}_{\mathrm{q} / 11}$ (2, B, and 3 in fig. 1), thereby triggering the activation of $\mathrm{PLC} \beta$, hydrolysis of PIP2 to diacylglycerol and IP3, and the mobilization of intracellular $\mathrm{Ca}^{2+}$, events implicated in GnRH neuronal membrane depolarization and GnRH secretion [39-44].

\section{KISS1R Displays Basal Constitutive Signaling and KP-Independent Internalization}

In addition to KISS1R displaying KP-triggered signaling and internalization [45], in HEK 293 cells transiently expressing KISS1R, KP-independent $\mathrm{Ga}_{\mathrm{q} / 11}$ signaling, and internalization are apparent (1 in fig. 1) [45]. In the 


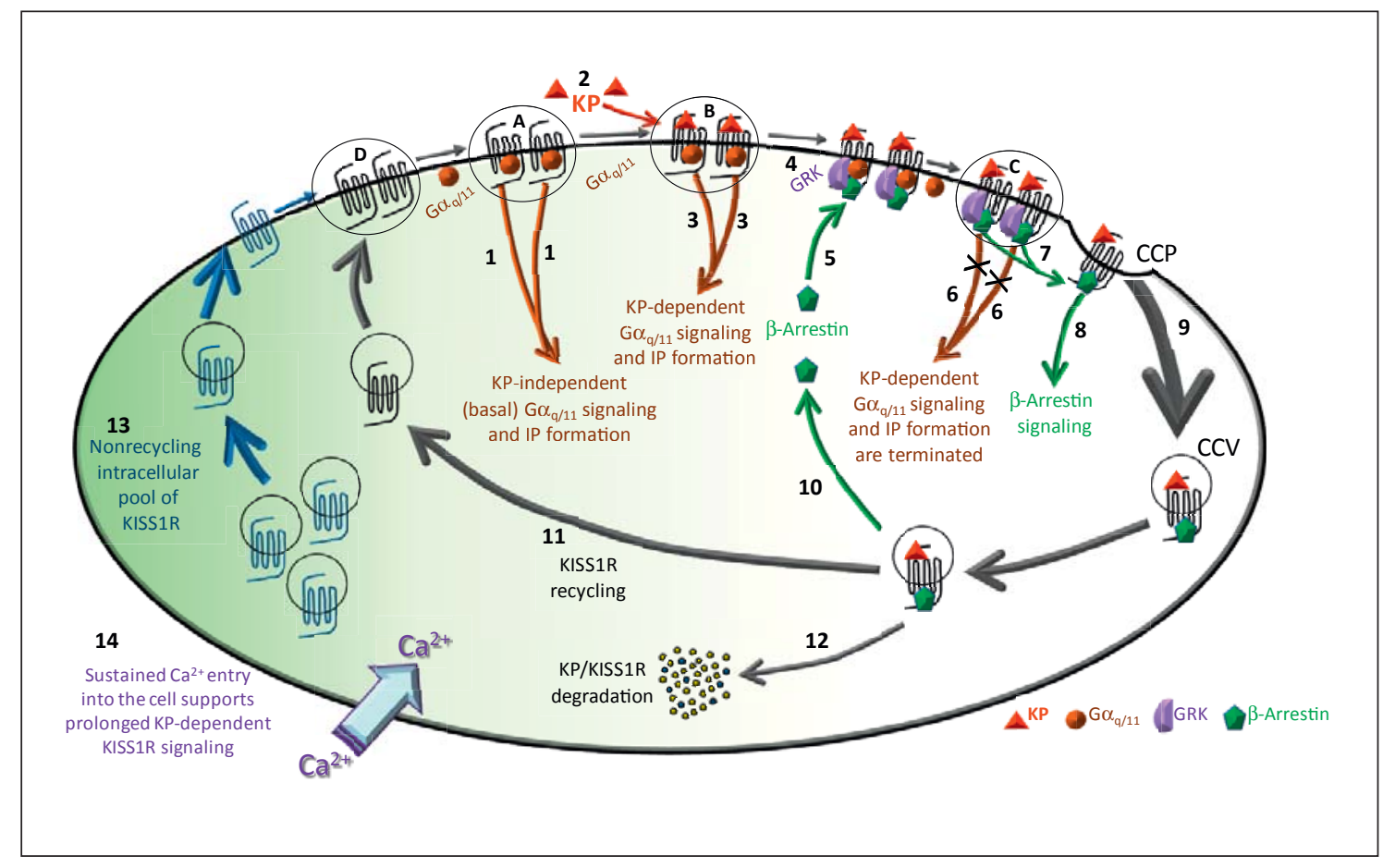

Fig. 1. Model of KISS1R signaling and trafficking in the cell. Numbers in parentheses refer the reader to specific illustrated events. At the cell surface, in the absence of KP, KISS1R couples to $\mathrm{Ga}_{\mathrm{q} / 11}$ (A) and exhibits KP-independent (basal) $\mathrm{Ga}_{\mathrm{q} / 11}$ signaling (as determined by IP formation) (1). In the presence of KP (2), KISS1R (B) exhibits increased $\mathrm{Ga}_{\mathrm{q} / 11}$ signaling (as determined by IP formation) (3) but through the rapid actions of GRK2 (4) and $\beta$-arrestin, which is recruited from the cytosol to the plasma membrane following KP treatment (5), KISS1R becomes uncoupled from $\mathrm{Ga}_{\mathrm{q} / 11}$ (desensitization) (C) and IP formation is terminated (6). In addition to uncoupling KISS1R from $\mathrm{Ga}_{\mathrm{q} / 11}, \beta$-arrestin simultaneously traffics the desensitized KISS1R to the clathrin-coated pit, resulting in sequestration (7). The sequestered receptor, which remains associated with $\beta$-arrestin, undergoes $\beta$-arrestin-dependent signaling (8) in addition to internalization via clathrin-coated vesicles (9). Though not depicted here, KISS1R also undergoes KP-inde-

absence of ligand, signaling is approximately $5 \%$ of the maximum KP-induced IP formation, an indirect measure of $\mathrm{Ga}_{\mathrm{q} / 11}$ activation (A and 1 in fig. 1). Moreover, internalization in the absence of ligand was very high, with about $70 \%$ of the labeled cell surface KISS1R internalizing after $5 \mathrm{~min}$ at $37^{\circ} \mathrm{C}$. This high basal internalization rate was even greater than that reported for the mammalian type I GnRH receptor (GnRH-RI), where after $90 \mathrm{~min}$ at $37^{\circ} \mathrm{C}$ about $25 \%$ of the receptor had internalized [46]. It was also higher than the metabotropic glutamate receptor $1 \mathrm{a}$, a receptor well known for its high constitutive internalization in heterologous cell cultures and primary neu- pendent internalization $[45,51]$. $\beta$-Arrestin eventually dissociates from internalized KISS1R (10) and the resensitized KISS1R traffics back to the cell surface (11), while a lesser population of KISS1R and KP are targeted for degradation (12). The population of cell surface signaling-competent KISS1R (D) is derived from recycling (11) receptors as well as nonrecycling receptors (13). The net result of KISS1R undergoing rapid uncoupling from $\mathrm{Ga}_{\mathrm{q} / 11}$, internalization, and continuous recycling to the cell surface, coupled to the trafficking of nonrecycling KISS1R to the cell surface, is that the cell maintains a signaling-competent and dynamic pool of KISS1R at its surface (A and B), resulting in prolonged KP-dependent signaling. Chronic KP signaling is also absolutely dependent on the sustained influx of extracellular $\mathrm{Ca}^{2+}$, which in turn is dependent on the continued presence of exogenous KP and dynamic trafficking of KISS1R (14). CCP = Clathrin-coated pit; CCV = clathrincoated vesicle. 
comes from studies performed on Kiss $\mathrm{I}^{-/}$and $\mathrm{Kiss} \mathrm{r}^{-/-}$ mice [17]. In that study, Lapatto et al. [17] reported that, compared to Kiss $1 r^{-/-}$female mice, Kiss ${ }^{-/-}$female mice displayed a more variable phenotype and they suggested that it could be the result of modest constitutive Kiss1r activity in the complete absence of endogenous KP. It is unlikely that the variable reproductive phenotype is the result of other RF-amide peptides activating Kiss $1 \mathrm{r}$ since binding experiments, performed on membranes from $\mathrm{CHO}$ cells expressing KISS1R, revealed a high affinity and remarkable selectivity for $\mathrm{KP}$; this is in contrast to the NPFF1/GPR147 and NPFF2/GPR74 receptors which display a high affinity for all RF-amides, including KP [52].

The question arises of whether constitutive KISS1R signaling is physiologically relevant. A putative role could be in maintaining the neuroendocrine axis in a primed state during development. The neuroendocrine axis is highly active during fetal life and in the neonatal period up to approximately 6 months in boys and 1-2 years in girls [53]. It has been suggested that the transient LH surge observed in the period after birth ('mini' puberty) might play a role in regulating the differentiation of spermatogonia and adult germ line stem cells $[54,55]$. This is followed by a period characterized by very low-amplitude LH secretion. With the onset of puberty in girls between the ages of 8 and 14 years and in boys between the ages of 9 and 14 years, there is a reactivation of the axis and a concomitant and robust increase in the amplitude of $\mathrm{GnRH}$-induced LH pulses with more modest changes in frequency [56-61]. Thus, keeping the axis in a primed or basal state of activity during many of the childhood years may facilitate its activation when KP-dependent signaling is fully established.

This idea that basal GnRH secretion keeps the pituitary-gonadal axis primed is supported by several studies conducted on laboratory animals and human patients. For example, in the hypogonadal $(h p g)$ mouse it was observed that administration of $40 \mathrm{ng}$ of a $\mathrm{GnRH}$ analog could immediately trigger $\mathrm{LH}$ secretion from the pituitary, albeit significantly lower than that in normal mice [62]. In the rhesus monkey (Macaca mulatta), the responsiveness of pituitary gonadotropes to GnRH stimulation is clearly enhanced by a preceding chronic pulsatile infusion of GnRH [63]. This important observation led Plant and colleagues [64-68] to employ a standard $\mathrm{GnRH}$ priming protocol in their studies where gonadotropin secretion is measured in response to various factors. Studies have also been conducted in men exhibiting gonadotropin deficiency, and in the absence of any pituitary defects it has been reported that $\mathrm{GnRH}$ priming im- proves gonadotropin secretion $[69,70]$. More detailed studies in human male patients are generally lacking because males who are diagnosed with $\mathrm{GnRH}$ and gonadotropin deficiency often exhibit pituitary and testicular defects [71]. GnRH priming is not only believed to be important for the normal onset of puberty. In reproductively mature female animals, including human females, it has also been proposed that $\mathrm{GnRH}$ secreted during progression of the follicular phase increases the number of GnRH receptors on gonadotropes and this serves to potentiate the LH preovulatory surge [72-74]. Thus, the constitutive activity of KISS1R may act to prime the gonadotrope.

\section{$\beta$-Arrestin Coupling in KISS1R Signaling}

Traditionally, $\beta$-arrestins are recognized as molecules that mediate the homologous desensitization and clathrin-dependent endocytosis of GPCRs [75]; these are discussed further below. Importantly, it is now well established that $\beta$-arrestins play much wider roles in regulating GPCR signaling than previously thought. Specifically, they serve as molecular scaffolds that couple GPCRs to a variety of signaling pathways, thus acting as signal transducers in their own right [76-78]. Since the first report that $\beta$-arrestins can couple the tyrosine kinase $c$-Src to the agonist-activated $\beta_{2}$-adrenergic receptor ( $\beta 2 \mathrm{AR}$ ), eventually leading to $G$ protein-independent activation of ERK1/2, numerous studies have demonstrated that $\beta$-arrestins can couple GPCRs to a large array of signaling pathways including $\mathrm{p} 38$, c-Jun $\mathrm{N}$ terminal kinase-3, AKT, PI3 kinase, and phosphodiesterase 4 [76, 79].

The first evidence that KISSR could signal via $\beta$-arrestins ( 8 in fig. 1 ) came from the observations that KISS1R physicallyinteractsstrongly with both $\beta$-arrestin- 1 and $\beta$-arrestin- 2 and that $\beta$-arrestin and KISS1R colocalize to clathrin-coated pits [45], structures that have been reported to facilitate the $\beta$-arrestin-dependent coupling of GPCRs to $G$ protein-independent pathways ( 8 in fig. 1) [75]. However, in the case of KISS1R, it remains to be determined whether localization to clathrin-coated pits and even internalization via clathrin-coated vesicles are required for $\beta$-arrestin-dependent signaling. It has also been demonstrated that KP-triggered ERK1/2 phosphorylation is significantly diminished in MDA-MB-231 breast cancer cells in which $\beta$-arrestin-2 is depleted and in mouse embryonic fibroblasts lacking $\beta$-arrestin- 1 and $\beta$-arrestin-2 $[45,80]$. These findings led to the hypothesis that in the GnRH neuron, in addition to coupling to 
$\mathrm{Ga}_{\mathrm{q} / 11}$, KISS1R couples to $\beta$-arrestin to regulate $\mathrm{GnRH}$ secretion. To test this hypothesis, KP-dependent LH secretion, a surrogate marker of $\mathrm{GnRH}$ secretion, was measured in mice lacking either $\beta$-arrestin-1 or $\beta$-arrestin- 2 and the results revealed that $\mathrm{LH}$ secretion was significantly diminished relative to WT littermates, thus supporting that $\beta$-arrestin mediates KP-induced GnRH secretion [81]. This conclusion was only possible because it is wellestablished that $\mathrm{GnRH}$ receptor activity on the anterior pituitary is not regulated by $\beta$-arrestin $[46,82-85]$, and thus the observed reduction in $\mathrm{GnRH}$ secretion must have occurred as the result of an absence of $\beta$-arrestinregulated events in the GnRH neuron following KP treatment. It is suggested that $\mathrm{KP}$-triggered $\beta$-arrestin signaling is of physiological importance and such signaling might explain why patients bearing some types of $\mathrm{Ga}_{\mathrm{q} / 11^{-}}$ uncoupled KISS1R mutants display a partial gonadotropic deficiency.

\section{KISS1R Ga $a_{\mathrm{q} / 11}$-Coupled Signaling Undergoes Homologous Desensitization}

Homologous desensitization refers to the uncoupling of the GPCR from its cognate G protein in the continuous presence of its agonist. This singular event, which is characteristically rapid, occurs within seconds to minutes, terminates $G$ protein-dependent signaling which is crucial to neuronal signaling, and protects the cell from being overstimulated by an agonist. Homologous desensitization is well understood for $\beta 2 \mathrm{AR}$, and based on this a general model of the phenomenon for this GPCR has been proposed. In this model, the ligand (L) binds its GPCR (R) and stabilizes an active conformation of the receptor $\left(R^{*}\right)$ that allows recruitment of the signaling $G$ protein $\left(\mathrm{Ga}_{\mathrm{s}}\right.$ in this case). The activated receptor then binds one or more of the GPCR serine/threonine kinases (GRKs; of which there are 7), which phosphorylate the receptor at cognate residues on its intracellular loops and carboxyl terminal tail. Phosphorylation promotes highaffinity binding of the arrestin family of proteins, the visual arrestins and the nonvisual arrestins ( $\beta$-arrestin-1 and $\beta$-arrestin-2) to the receptor and this sterically hinders the interaction between the GPCR and the G protein [75].

In addition to uncoupling the GPCR from its cognate $\mathrm{G}$ protein, $\beta$-arrestin simultaneously couples and sequesters the desensitized GPCR to clathrin-coated pits via direct interaction. Sequestration into clathrin-coated pits serves multiple purposes. The first is that it prevents re- coupling of the desensitized GPCR to its G protein; the second is that it rapidly targets the uncoupled receptor for internalization where it can undergo degradation or resensitization, and the third is that for many GPCRs it provides an environment that allows $\beta$-arrestin to couple the sequestered receptor to new signaling pathways, thereby permitting $\beta$-arrestin-dependent signaling $[45,75-78$, 80].

As stated earlier, assaying the formation of IP by PIP2 hydrolysis is an indirect measure of $\mathrm{Ga}_{\mathrm{q} / 11}$ activation (A, $1, \mathrm{~B}$, and 3 in fig. 1). In this way it was demonstrated that in HEK 293 cells transiently expressing KISS1R, coexpression of GRK2 [45] or $\beta$-arrestin-1 or $\beta$-arrestin-2 [unpubl. data] significantly diminished the IP-forming capacity of these cells in response to increasing concentrations of KP following a 4-hour incubation period at $37^{\circ} \mathrm{C}$. These results suggest that following KP treatment ( 2 in fig. 1), GRK2 and $\beta$-arrestin uncouple KISS1R from$\mathrm{Ga}_{\mathrm{q} / 11}$ and IP generation (4, 5, C, and 6 in fig. 1). This conclusion is reinforced by the observations that KISS1R physically interacts with GRK2 and $\beta$-arrestin- 1 and $\beta$-arrestin- 2 and that within $3 \mathrm{~min}$ of $\mathrm{KP}$ stimulation $\beta$-arrestin molecules are recruited to the plasma membrane (5 in fig. 1) where they colocalize and rapidly cointernalize with KISS1R [45]. While it appears that $\beta$-arrestin is recruited to KISS1R in response to KP-triggered G protein signaling ( 5 in fig. 1 ), it is not known whether the association of GRK2 with KISS1R is also G protein dependent or whether GRK2 is constitutively associated with KISS1R. Nevertheless, it is clear that, in response to the KP-dependent activation of KISS1R, GRK2 acts to rapidly uncouple KISS1R from $\mathrm{Ga}_{\mathrm{q} / 11}$ [45]. At first consideration, the desensitization of KISS1R appears to be mechanistically identical to that of $\beta 2 \mathrm{AR}$. However, unlike $\beta 2 \mathrm{AR}$, but similar to the metabotropic glutamate receptor la $[86,87]$ and the calcium-sensing receptor [88], it was observed that following KP treatment GRK2 diminished IP formation in a phosphorylation-independent manner [45].

Since KISS1R colocalized with $\beta$-arrestin or clathrin at the cell surface and with $\beta$-arrestin or transferrin (a clathrin-coated vesicular cargo) in endosomes in a temporally overlapping manner, it was concluded that, like $\beta 2 \mathrm{AR}$, $\beta$-arrestin sequestered the G protein-uncoupled KISS1R to clathrin-coated pits (7 and 8 in fig. 1) and thus facilitated KISS1R internalization via clathrin-coated vesicles (9 in fig. 1). However, unlike $\beta 2$ AR but similar to the vasopressin V2 receptor [89], $\beta$-arrestin cointernalized with KISS1R in clathrin-coated vesicles (9 in fig. 1) [45] where intracellularly it is believed they eventually dissociate 
from each other (10 and 11 in fig. 1). Consistent with GPCRs that desensitize and internalize through a $\beta$-arrestinand a $\beta$-arrestin/clathrin-dependent mechanism, respectively, KISS1R desensitization and internalization were rapid and after only $5 \mathrm{~min}$ at $37^{\circ} \mathrm{C}$ approximately $80 \%$ of the receptor had undergone KP-dependent internalization as assessed by flow cytometry [45]. Notably, KISS1R internalization was rapid as it was about 2.5 times more rapid than $\beta 2 A R$ under saturating concentrations of their respective agonists [45].

In a recent study, using $\mathrm{CHO}$ cells stably expressing KISS1R, Bianco et al. [90] also demonstrated that KISS1R signaling undergoes desensitization (as assessed by IP formation) and internalization (by measuring radiolabeled KP-10 internalization). Specifically they showed that, following KP treatment, IP formation peaked after 2 $\mathrm{h}$ and returned to baseline by $12 \mathrm{~h}$ despite the continuous presence of KP (table 1). It must be noted that since this standard IP assay, like that conducted by Pampillo et al. [45], was conducted in the presence of LiCl, IPs were not rapidly degraded [91] and therefore the results of this study only confirm that KISS1R undergoes KP-dependent desensitization but they do not inform us on the rate of desensitization, which is likely to be more rapid than when using $\mathrm{LiCl}$ as an inhibitor of IP degradation. As for internalization, the authors showed that at $37^{\circ} \mathrm{C}$ after 15 min $50 \%$ of the KISS1R was internalized and after $60 \mathrm{~min}$ approximately $80 \%$ of the KISS1R was internalized as assessed by a loss of cell surface binding of the radioligand [90]. Therefore, consistent with the findings of Pampillo et al. [45], KISS1R internalization was rapid. Min et al. [51] further demonstrated that the endocytic inhibitor phenylarsine oxide significantly inhibited KISS1R internalization and this was consistent with the idea that ligand-dependent KISS1R internalization follows classic clathrin- and dynamin-mediated endocytosis pathways. Taken together, these studies $[45,51,90]$ indicate that GRK2 and $\beta$-arrestin mediate the rapid and homologous desensitization and internalization of KISS1R via clathrin-coated vesicles.

\section{KISS1R Undergoes Degradation and Recycling}

Both in the presence and in the absence of KP, the Kaiser laboratory $[51,90]$ demonstrated that KISS1R undergoes rapid dynamic internalization and recycling. These authors reported that with each wave of internalization the majority of KISS1R molecules recycled rapidly back to the cell surface (11 in fig. 1) while a small quantity of internalized receptor was degraded via proteasomes (12 in fig. 1). The interpretation of these observations is that if this is characteristic of KISS1R in GnRH neurons, neurons would maintain a pool of KISS1R at their surface and if the recycled receptors were functionally competent they could support sustained or prolonged KP-dependent signaling. This is discussed further in the subsequent section. Importantly, while only a small fraction of the internalized KISS1R had undergone degradation, within an hour of internalization most of the ligand was rapidly processed and degraded [51], thus representing a potential alternative mechanism for the termination of neuropeptide action. It was reported that receptors like the angiotensin II type 1 A receptor, neurotensin receptor 1, the vasopressin V2 receptor, the thyrotropin-releasing hormone receptor, and the substance $\mathrm{P}$ receptor, which bind $\beta$-arrestin- 1 and $\beta$-arrestin- 2 with similar high affinities and cointernalize with $\beta$-arrestin in endosomes, are retained intracellularly and recycle very slowly if at all $[89,92]$. However, while KISS1R also binds $\beta$-arrestin- 1 and $\beta$-arrestin- 2 with similar high affinities and cointernalizes with $\beta$-arrestin in endosomes [45], most KISS1R molecules recycle back to the cell surface [51].

While the Kaiser laboratory [51, 90] clearly demonstrated that recycling KISS1R contributed significantly to the dynamic population of cell surface receptors, they considered the possibility that an intracellular pool of nonrecycling receptors also contributed to this receptor population at the plasma membrane. The existence of such an intracellular pool is highly probable given that it was previously observed that KISS1R was present at very high levels intracellularly in at least two unrelated celltypes [45]. Definitive proof of the existence of a nonrecycling intracellular pool of KISS1R eventually came from Min et al. [51], and in that study the authors demonstrated that this intracellular population of receptors did in fact traffic to the plasma membrane independently of KP (13 in fig. 1). This is a major finding since it reveals an important mechanism by which the cell maintains a large population of presumably signaling-competent KISS1R at the cell surface despite receptor internalization and degradation and thereby contributes to the dynamic pool of ligand-responsive KISS1R at the cell surface [51]. The high intracellular content of KISS1R is similar to that described for the GnRH receptor and the relaxin receptor RXFP1 [93-95]. Potentially, intracellular retention of receptors creates and provides a source of receptors needed for rapid availability without transcription or translation. 
Table 1. Effect of chronic and repeated KP (naturally occurring and stable synthetic agonists) exposure on KP-dependent signaling events

\begin{tabular}{llll}
\hline $\begin{array}{l}\text { Animal species/ } \\
\text { cell line }\end{array}$ & KP administration & KP type and dose & $\begin{array}{l}\text { KP-dependent signaling } \\
\text { event used to assess } \\
\text { desensitization }\end{array}$
\end{tabular} \begin{tabular}{l}
$\begin{array}{l}\text { Time point at which } \\
\text { desensitization was detected } \\
\text { following the start of treatment }\end{array}$ \\
\hline
\end{tabular}

Naturally occurring KPs - in vivo studies

Ovariectomized Continuous i.c.v.

ewes treated with administration with a

estradiol implants portable syringe pump
KP-10; flow rate: $3 \mu \mathrm{l} /$ min, concentration: 0.2 $\mu \mathrm{g} / \mathrm{min}(\sim 9.2 \mathrm{nmol} / \mathrm{h})$,

$\sim 37$ nmol administered over a 4-hour infusion period

\begin{tabular}{ll}
\hline Adult male rats & Continuous s.c. infusion \\
via osmotic mini pumps
\end{tabular}

total: $50 \mathrm{nmol} /$ day
GnRH and LH secretion

every $10 \mathrm{~min}$

LH: detected within 1-2 h;

GnRH: not detected during

the 4-hour infusion period
100

KP-54; flow rate: $1 \mu \mathrm{l} / \mathrm{h}$,

$(\sim 2 \mathrm{nmol} / \mathrm{h})$

Agonadal juvenile Continuous i.v. infusion KP-10;100 $\mu \mathrm{g} / \mathrm{h}$

male monkeys

$(\sim 77 \mathrm{nmol} / \mathrm{h})$ for $98 \mathrm{~h}$

$(\sim 7.5 \mathrm{mmol} / 98 \mathrm{~h})$

$\begin{array}{ll}\text { LH and testosterone } & \begin{array}{l}\text { Detected after } 2 \text { days but not } \\ \text { secretion measured on }\end{array}\end{array}$ day 2

LH secretion during the

first $12 \mathrm{~h}$ of continuous

infusion 10, 20, 30, 50, 70,
Detected after 1-2 h

68
$90,110,130,150,170,360$,

and $720 \mathrm{~min}$ into the

infusion

\begin{tabular}{llll}
\hline Male rats & $\begin{array}{l}\text { Repeated administration } \\
\text { (4 boluses 75 min apart) }\end{array}$ & $\begin{array}{l}\text { KP-10; } 30 \mathrm{nmol} / \mathrm{kg} \text { of } \\
\text { body weight }\end{array}$ & LH secretion every $15 \mathrm{~min}$ \\
\hline $\begin{array}{l}\text { Gonad-intact adult } \\
\text { male monkey }\end{array}$ & Continuous i.v. infusion & $\begin{array}{l}\mathrm{KP}-10 ; 200 \mu \mathrm{g} / \mathrm{h} \\
(\sim 154 \mathrm{nmol} / \mathrm{h}) \text { or }\end{array}$ & $\begin{array}{l}\text { LH secretion during the } \\
\text { first } 12 \mathrm{~h} \text { of continuous }\end{array}$ \\
& & $\begin{array}{l}400 \mu \mathrm{g} / \mathrm{h}(\sim 308 \mathrm{nmol} / \mathrm{h}) \\
\text { for } 98 \mathrm{~h}\end{array}$ & $\begin{array}{l}\text { infusion } 10,20,30,50,70, \\
90,110,130,150,170,360\end{array}$ \\
& & $\begin{array}{l}\text { and } 720 \text { min into the } \\
\text { infusion }\end{array}$
\end{tabular}

Female rats: adult Continuous i.c.v. KP-10; flow rate: fed and underfed, administration with an $1 \mu \mathrm{l} / \mathrm{h}, 7.5 \mathrm{nmol} /$ day and PP fed and underfed $(\sim 0.3 \mathrm{nmol} / \mathrm{h})$
Detected after 2-3 h adult fed/FSH: not detected by

day 7; adult underfed/LH: detected on day 7 ; adult
Start of treatment: day 0; adults: $\mathrm{LH}$ and FSH, 1 measurement/day; PP rats: a single LH/FSH measurement on day 7

Not detected over a 5-hour
assay period

102

Adult fed/LH: detected on day 3; 103 underfed/FSH: detected on day 3; $\mathrm{PP}$ rat fed/LH and FSH: not detected by day 7; PP rat underfed/LH and FSH: not detected by day 7 and responses were greater than those of $\mathrm{PP}$ rats fed on day 7

\begin{tabular}{|c|c|c|c|c|c|}
\hline $\begin{array}{l}\text { Women with } \\
\text { hypothalamic } \\
\text { amenorrhea }\end{array}$ & $\begin{array}{l}\text { Intermittent } \\
\text { administration; data } \\
\text { suggest that high KP } \\
\text { levels are maintained } \\
\text { between injections }\end{array}$ & $\begin{array}{l}\text { KP-54; twice daily } \\
\text { i.v. injections, } \\
6.4 \mathrm{nmol} / \mathrm{kg} / \text { injection }\end{array}$ & $\begin{array}{l}\text { LH, FSH, and estradiol } \\
\text { secretion, } 11 \text { readings } \\
\text { taken over a } 240 \text {-min } \\
\text { period after the first and } \\
\text { last KP injections on day } 1 \\
\text { and day } 14\end{array}$ & $\begin{array}{l}\text { Detected on day } 14 \text {, but not } \\
\text { before the first } 6 \mathrm{~h} \text { after the first } \\
\text { injection on day } 1\end{array}$ & 104 \\
\hline Healthy men & Continuous i.v. infusion & $\begin{array}{l}\mathrm{KP}-10 ; 4 \mu \mathrm{g} \\
(\sim 3 \mathrm{nmol}) / \mathrm{kg} / \mathrm{h}\end{array}$ & $\begin{array}{l}\text { LH secretion every } 10 \mathrm{~min} \\
\text { during the wake period } \\
\text { and every hour during the } \\
\text { sleep period }\end{array}$ & $\begin{array}{l}\text { Not detected after } 22.5 \mathrm{~h} \\
\text { [and up to } 36 \mathrm{~h} \text {, unpubl. data] }\end{array}$ & 105 \\
\hline $\begin{array}{l}\text { Male patients with } \\
\text { loss-of-function } \\
\text { mutations in NKB } \\
\text { (TAC3) or its } \\
\text { receptor (TAC3R) }\end{array}$ & Continuous i.v. infusion & $\begin{array}{l}\mathrm{KP}-10 ; 1.5 \mu \mathrm{g} \\
(\sim 1.2 \mathrm{nmol}) / \mathrm{kg} / \mathrm{h}\end{array}$ & $\begin{array}{l}\text { LH and FSH secretion } \\
\text { every } 10 \text { min for } 12 \text { h over } \\
2 \text { consecutive days }\end{array}$ & Not detected after $12 \mathrm{~h}$ & 106 \\
\hline
\end{tabular}


Table 1 (continued)

\begin{tabular}{|c|c|c|c|c|c|}
\hline $\begin{array}{l}\text { Animal species/ } \\
\text { cell line }\end{array}$ & KP administration & KP type and dose & $\begin{array}{l}\text { KP-dependent signaling } \\
\text { event used to assess } \\
\text { desensitization }\end{array}$ & $\begin{array}{l}\text { Time point at which } \\
\text { desensitization was detected } \\
\text { following the start of treatment }\end{array}$ & Reference \\
\hline \multicolumn{6}{|c|}{ Naturally occurring KPs - in vitro studies } \\
\hline $\begin{array}{l}\text { Mouse mediobasal } \\
\text { hypothalamic } \\
\text { explants }\end{array}$ & Continuous incubation & $\mathrm{KP}-10 ; 50 \mathrm{nM}$ & $\begin{array}{l}\text { GnRH secretion measured } \\
\text { every hour over a 6-hour } \\
\text { assay period }\end{array}$ & Detected after 5-6 h & 107 \\
\hline $\begin{array}{l}\text { CHO cells stably } \\
\text { expressing KISS1R }\end{array}$ & Continuous incubation & KP-10; $100 \mathrm{nM}$ & $\begin{array}{l}\text { Total IP formation } \\
\text { following } 1,2,4,12 \text {, and } \\
18 \text { h of treatment of cells }\end{array}$ & $\begin{array}{l}\text { Detected after } 2 \mathrm{~h} \text {, presumably } \\
\text { occurred earlier }\end{array}$ & 90 \\
\hline $\begin{array}{l}\text { GT1-7 and HEK } \\
293 \text { cells } \\
\text { transiently } \\
\text { expressing KISS1R }\end{array}$ & Continuous incubation & $\mathrm{KP}-10 ; 100 \mathrm{nM}$ & $\begin{array}{l}\text { Spatiotemporal properties } \\
\text { of PLC } \beta \text { and PKC } \\
\text { activation and intracellular } \\
\mathrm{Ca}^{2+} \text { mobilization }\end{array}$ & Detected at $45-90 \mathrm{~min}$ & 96 \\
\hline
\end{tabular}

Synthetic KP agonists - in vivo studies

Adult male rats Continuous s.c. infu

with an osmotic mini $\quad 0.2-4.0 \mathrm{nmol} / \mathrm{h}$;

Testosterone secretion

KISS1-305: castrate levels

108

pump

TAK-448: $0.1 \mathrm{nmol} / \mathrm{h}$

achieved by day 3 at $1-4 \mathrm{nmol} / \mathrm{h}$

TAK-448: detected by day 3 and depleted testosterone content by week 4

\begin{tabular}{|c|c|c|c|c|c|}
\hline $\begin{array}{l}\text { Healthy human } \\
\text { males }\end{array}$ & $\begin{array}{l}\text { Administered as a single } \\
\text { s.c. dose on day } 1 \\
\text { followed by a } 13 \text {-day } \\
\text { continuous infusion via } \\
\text { an ambulatory pump } \\
\text { from day } 2 \text { to day } 14\end{array}$ & $\begin{array}{l}\text { TAK-683; single s.c. } \\
\text { dose on day } 1 \text { ( } 0.03- \\
1.0 \mathrm{mg}) \text { followed by } \\
\text { continuous infusion } \\
\text { from day } 2 \text { to day } 14 \\
(0.01-2.0 \mathrm{mg} / \text { day) to } \\
\text { simulate depot } \\
\text { formulation }\end{array}$ & Testosterone secretion & $\begin{array}{l}\text { Subcastrate levels achieved by } \\
\text { day } 7 \text {, with concentrations of } 2.0 \\
\text { mg/day on day } 2 \text { to day } 14\end{array}$ & 110 \\
\hline Adult male rats & $\begin{array}{l}\text { Single daily s.c. injection } \\
\text { and continuous s.c. } \\
\text { infusion with an osmotic } \\
\text { mini pump }\end{array}$ & $\begin{array}{l}\text { TAK- } 448 \text { and TAK- } 683 \\
(0.008-8 \mu \mathrm{mol} / \mathrm{kg}) \\
\text { administered for } 7 \text { days, } \\
\text { continuous s.c. infusion } \\
\text { of TAK-448 } \\
(\sim 0.7 \mathrm{nmol} / \mathrm{kg} / \text { day }) \\
\text { and TAK-683 ( } 2.1 \\
\text { nmol } / \mathrm{kg} / \text { day })\end{array}$ & $\begin{array}{l}\text { LH and testosterone } \\
\text { secretion }\end{array}$ & $\begin{array}{l}\text { Detected by day } 4 \text { with repetitive } \\
\text { single s.c. injections, with } \\
\text { continuous infusion, castrate } \\
\text { levels of testosterone were } \\
\text { detected within } 3-7 \text { days }\end{array}$ & 111 \\
\hline $\begin{array}{l}\text { Healthy human } \\
\text { male subjects aged } \\
50 \text { years or older } \\
\text { and prostate } \\
\text { cancer patients } \\
\text { aged } 40-78 \text { years }\end{array}$ & $\begin{array}{l}\text { Healthy subjects: 14-day } \\
\text { s.c. administration, day } \\
\text { 1: bolus injection, days } \\
2-14 \text { : continuous } \\
\text { infusion using a } \\
\text { standard insulin } \\
\text { infusion pump. Cancer } \\
\text { patients: } 1 \text {-month depot } \\
\text { formulation }\end{array}$ & $\begin{array}{l}\text { TAK- } 448 \text {; healthy } \\
\text { subjects: } 0.1 \mathrm{mg} \text { s.c. } \\
\text { bolus on day } 1 \text {, s.c. } \\
\text { infusion on days } 2-14 \\
\text { (total daily dose of } 0.01 \text {, } \\
0.1,0.3 \text {, or } 1 \mathrm{mg} / \text { day); } \\
\text { prostate cancer } \\
\text { patients: } 1 \text {-month } \\
\text { depot formulation } \\
(6,12 \text {, or } 24 \mathrm{mg})\end{array}$ & Testosterone secretion & $\begin{array}{l}\text { Healthy subjects: at doses above } \\
0.1 \mathrm{mg} / \text { day, subbaseline } \\
\text { testosterone levels achieved by } 60 \\
\text { h and subcastration levels } \\
\text { reached by day } 8 \text {; cancer patients: } \\
\text { significant decline in testosterone } \\
\text { levels detected by day } 10 \text { in all } \\
\text { patients dosed with } 12 \text { - or } 24-\mathrm{mg} \\
\text { TAK- } 448 \text { s.c. depot injections. } \\
\text { Suppression was maintained in } \\
4 / 5 \text { patients during the treatment } \\
\text { period }\end{array}$ & 112 \\
\hline Goats & $\begin{array}{l}\text { Continuous s.c. infusion } \\
\text { via osmotic mini pumps }\end{array}$ & $\begin{array}{l}\text { TAK- } 683 ; 0.03,0.3 \text {, or } \\
3 \mathrm{nmol} / \mathrm{h} / \mathrm{kg} \text {, flow rate: } \\
10 \mu \mathrm{l} / \mathrm{h}\end{array}$ & LH secretion every $3 \mathrm{~h}$ & $\begin{array}{l}\text { Detected in as little as } 1 \text { day and } \\
\text { with marked suppression by } \\
\text { day } 3\end{array}$ & 109 \\
\hline
\end{tabular}

$\mathrm{PP}=$ Peripubertal 


\section{KP-Dependent Signaling following Chronic KP Exposure Is Resistant to Rapid Desensitization in Cultured Cell Lines}

Once it was established that the cell maintains a dynamic population of cell surface KISS1R, it was determined whether this resulted in continuous or prolonged $\mathrm{KP}$ signaling. If it did then chronic KP administration should result in the sustained activation of the $\mathrm{Ga}_{\mathrm{q} / 11^{-}}$ coupled signaling pathway [96]. To test this, HEK 293 and the GnRH-secreting GT1-7 cells [97] transiently coexpressing KISS1R and molecular reporters of $\mathrm{Ga}_{\mathrm{q} / 11^{-}}$ coupled signaling were treated chronically with KP-10 and assessed for $\mathrm{Ga}_{\mathrm{q} / 11}$-dependent signaling. Based on the spatiotemporal properties of PLC $\beta$ and PKC activation and intracellular $\mathrm{Ca}^{2+}$ mobilization, it was concluded that chronic KP-10 administration triggers prolonged signaling [96]. For example, in HEK 293 and GT1-7 cells, the initial desensitization of PLC $\beta$ activation was observed after about 90 and $45 \mathrm{~min}$, respectively, while for PKC activation it was detected after about 45 min in HEK 293 cells (table 1). To put this into striking perspective, in HEK 293 cells transiently expressing the $\mathrm{Ga}_{\mathrm{q} / 11}$-coupled endothelin or angiotensin receptors, chronic stimulation by their respective ligands triggered a rapid activation of PKC that was either fully desensitized or nearly so after just $80 \mathrm{~s}$ [98].

Thus, the study described above [90] led to the conclusion that the dynamic pool of plasma membrane-bound KISS1R identified by Bianco et al. [90] is a signaling-competent pool capable of responding to chronically administered $\mathrm{KP}$ and thereby resulting in sustained signaling via $\mathrm{Ga}_{\mathrm{q} / 11}$. This conclusion, however, was not consistent with the observations that in HEK 293 cells, just after 5 min at $37^{\circ} \mathrm{C}$, approximately $80 \%$ of transiently expressed KISS1R had undergone agonist-dependent internalization [45] $[51,90]$ and presumably desensitization of $\mathrm{Ga}_{\mathrm{q} / 11^{-} \text {-coupled }}$ signaling [45]. However, when considered together, these studies [45, 51, 90, 96] reveal that it is 'KISS1R-expressing cells', and not the 'receptors', which exhibit prolonged signaling following chronic KP administration. Furthermore, this prolonged signaling is dependent on the rapid desensitization, internalization, and recycling of resensitized KISS1R molecules superimposed on a background of diminished receptor degradation (fig. 1). Because of this dynamic trafficking and signaling, at any point in time, KISS1R is found to be associated with $\mathrm{Ga}_{\mathrm{q} / 11}$, GRK2, and $\beta$-arrestin [45]. Chronic KP signaling is also absolutely dependent on the sustained influx of extracellular $\mathrm{Ca}^{2+}$, which in turn is dependent on the continued pres- ence of exogenous KP and dynamic trafficking of KISS1R (14 in fig. 1) [51, 96]. The net result of this interesting phenomenon is that the cell maintains a dynamic and active pool of receptors at its surface ( $D$ in fig. 1 ), allowing it to display prolonged KP-dependent signaling (2, B, and 3 in fig. 1). Conceivably, this would protect against downregulation of the neuroendocrine axis.

\section{KP-Dependent Signaling in vivo Displays a Wide Range of Temporal Responses following Chronic Exposure to Exogenous KP}

Over the last decade, studies conducted on mice, rats, sheep, monkeys, and humans have examined the desensitization of KP signaling following chronic exposure to KP (summarized in table 1) [68,99-113] and, while most studies detected desensitization during the course of investigation, the temporal aspect of desensitization was surprisingly widely variable, ranging from $1-2 \mathrm{~h}$ to greater than $24 \mathrm{~h}$. Based on several studies investigating the desensitization of GPCRs, including KISS1R, there is evidence strongly suggesting that the range of temporal responses following chronic exposure of a receptor-expressing system to its agonist is in part due to differences in ligand efficacy and concentration [108-114] as well as differences in developmental (which would reflect differences in circulating levels of gonadal steroids) and metabolic status [103].

An example of one study reporting that KP signaling is desensitized relatively quickly comes from Plant and colleagues [68] who in 2006 reported that in agonadal juvenile male monkeys continuous intravenous infusion of human KP-10 (100 $\mu \mathrm{g} / \mathrm{h}$ for $98 \mathrm{~h})$ elicited a robust $\mathrm{LH}$ response that peaked after 1-2 h. However, despite the continuous infusion of KP-10, this was followed by a rapid drop in LH where, $12 \mathrm{~h}$ after the infusion, levels were similar to those in vehicle-infused animals (table 1). Thus, the authors concluded that the rapidly diminished response to chronic KP exposure was due to desensitization of KISS1R and was not the result of compromised GnRH secretion or reduced gonadotrope function. In a second study [102], the Plant laboratory extended their investigation to the gonad-intact adult male monkey, a preclinically relevant model that exhibits a highly active HPG axis. Here they found that continuous intravenous infusion of KP-10 (200 or $400 \mu \mathrm{g} / \mathrm{h}$ ) triggered a significant rise in circulating $\mathrm{LH}$ that peaked $2-3 \mathrm{~h}$ after the initiation of treatment and then rapidly declined by $24 \mathrm{~h}$ to levels similar to those in control animals (table 1). Those results led 
the authors to conclude that chronic KP exposure triggers the rapid desensitization of KISS1R signaling in adult male monkeys as in agonadal juvenile male monkeys. They also found that at $400 \mu \mathrm{g} / \mathrm{h}$ there was greater suppression of LH pulses but, since this was observed in the presence of impaired pituitary function, the greater suppressive effect was likely the result of pituitary desensitization at the higher KP-10 concentration rather than greater KISS1R desensitization.

At the other extreme of the temporal spectrum, clinical studies by Millar and colleagues [105, 106] (table 1) showed that chronically administered KP-10 does not result in rapid desensitization of KP signaling but instead elicits prolonged and pulsatile secretion of LH. Specifically, George et al. [105] reported that in healthy men, chronic infusion of KP-10 at the rate of $4 \mu \mathrm{g} / \mathrm{kg} / \mathrm{h}$ triggered multiple large LH pulses without evidence of desensitization over a 22-hour period (table 1) (indeed, they have demonstrated in unpublished studies that there is no evidence of desensitization for up to $36 \mathrm{~h}$ ). The observation that chronic KP-10 administration triggers pulsatile $\mathrm{LH}$ release is not confined to healthy individuals. In a subsequent study, the group [106] reported that $12 \mathrm{~h}$ of chronic KP-10 infusion administered at a rate of $1.5 \mu \mathrm{g} /$ $\mathrm{kg} / \mathrm{h}$ restored pulsatile gonadotropin secretion in male patients with loss-of-function mutations in NKB (TAC3) or its receptor (TAC3R) (table 1). These interesting findings reveal that chronically administered KP-10 can support prolonged gonadotropin secretion and that chronically administered KP-10 is sufficient to elicit a pulsatile release of $\mathrm{GnRH}$, as determined by the observed pulsatile release of LH. While pulsatile LH secretion was not desensitized during the period of investigation, it is predicted that such secretion would eventually desensitize. This is supported by the observation that within 1 day chronic exposure to KP-54 did not result in desensitization of $\mathrm{LH}$, FSH, or estradiol secretion in women exhibiting hypothalamic amenorrhea but sometime after the first day and possibly as late as the 14th day of chronic exposure full desensitization occurred (table 1) [104].

The above studies from the Plant and Millar laboratories clearly illustrate the wide range of temporal responses in gonadotropin secretion in response to chronic KP exposure $[68,102,105,106]$. While the dose-response study by Plant and colleagues [102] could not establish a relationship between KP concentration and the rate of KISS1R desensitization, several studies using synthetic KP analogs would subsequently do so (table 1) [108, 110113]. For example, in a recent study from the Okamura laboratory [113], the authors examined the effects of chronically administered KP agonist TAK-683 (an investigational protease-resistant agonist which exhibits improved pharmacokinetics and higher affinities than natural ligands) on LH secretion in goats. An osmotic pump containing TAK-683 $(0.03,0.3$, or $3 \mathrm{nmol} / \mathrm{h} / \mathrm{kg})$ was subcutaneously implanted (day 0 ) and TAK-683 was observed to suppress LH secretion as early as on day 1 and with marked suppression on day 5. On day 3 , at the lowest concentration suppression was marginal and LH pulses were still apparent; however, as the dose increased the suppressive effect on LH secretion became strikingly apparent. By day 3, at all concentrations, LH secretion was almost completely suppressed and the potent suppressive effect of continuous TAK-683 treatment was maintained until day 6 (table 1). The results indicated that chronic administration of the KP agonist, in a dose-dependent manner, profoundly suppresses pulsatile LH secretion while additional controls showed it did so without affecting the GnRH content, pituitary function, or GnRH pulse generator activity.

In addition to agonist concentration, the following study showed that agonist efficacy also regulates desensitization responses. When adult male rats were continuously infused over a 4 -week period with $0.2-4.0 \mathrm{nmol} / \mathrm{h}$ KISS1-305 (a protease-resistant agonist with suboptimal KISS1R agonistic activity in vitro) and $0.1 \mathrm{nmol} / \mathrm{h}$ TAK448 (a derivative of KISS1-305; a protease-resistant agonist with potent agonist activity comparable to KP-10), treatment with 1-4 nmol/h KISS1-305 resulted in castrate levels of testosterone $(<0.5 \mathrm{ng} / \mathrm{ml})$ by day 3 but its efficacy over the 4 -week treatment period was only sustained at $2 \mathrm{nmol} / \mathrm{h}$ and greater. Thus, $2 \mathrm{nmol} / \mathrm{h}$ was considered the minimum effective dose of KISS1-305. In contrast, TAK-448, which exhibits greater efficacy, induced testosterone depletion as rapidly as KISS1-305 but at a lower dose $(0.1 \mathrm{nmol} / \mathrm{h})$ (table 1$)$. Compared with previous studies using KP-54 in rats [99] or KP-10 in monkeys [102] (table 1), these studies with KISS1-305 and TAK-448 showed a greater reduction in plasma testosterone levels, leading the authors to suggest that the difference in efficacy is probably due to the higher stability of the KP analogs [115-118].

In the rat, desensitization of gonadotropin responses to KP is also influenced by developmental and metabolic states. This has been seen in studies using adult and peripubertal female rats which are fed or underfed and subjected to continuous i.c.v. administration of KP-10 $(1 \mu \mathrm{l} / \mathrm{h}, 7.5 \mathrm{nmol} /$ day) [103]. In adult fed rats, LH secretion declined on day 3, while FSH secretion remained elevated as long as day 7. In adult underfed rats, the results 
were reversed and a decline in LH secretion was not detected until day 7 while desensitization in FSH secretion was detected on day 3. In peripubertal fed and underfed rats, LH and FSH secretion remained elevated on day 7 , with gonadotropin responses being greater in underfed females (table 1). In man, however, an altered metabolic state does not alter the responsiveness to KP. As discussed earlier, Millar and colleagues [105] reported that chronically administered $\mathrm{KP}-10(4 \mu \mathrm{g} / \mathrm{kg} / \mathrm{h})$ to healthy men triggered an increase in LH secretion (5.4 \pm 0.7 to $20.8 \pm 4.9$ IU/l) without evidence of desensitization over a 22-hour period. When the same amount of KP-10 was infused intravenously for $11 \mathrm{~h}$ into obese hypotestosteronaemic men with type 2 diabetes, an altered metabolic state, $\mathrm{LH}$ secretion also increased $(3.9 \pm 0.1$ to $20.7 \pm 1.1 \mathrm{IU} / \mathrm{l})$ to an almost identical level [119]. Furthermore, like that seen in healthy men, there was no evidence of desensitization in LH secretion over the 11-hour period. Thus, in men displaying a perturbed afferent metabolic and endocrine input, $\mathrm{KP}$ responsiveness is preserved.

In conclusion, while a growing number of studies using naturally occurring and synthetic KP analogs show that chronic KP administration results in the desensitization of KP signaling, the temporal responses are dependent on a number of factors including ligand efficacy and concentration and the physiological, developmental, and metabolic status of the organism.

\section{In the Reproductively Mature Female, KISS1R Signaling Is Modulated by Circulating Sex Steroids}

In a study from the Terasawa laboratory [120], the authors showed that direct infusion of KP-10 (10 or $100 \mathrm{nM}$ infused over $10 \mathrm{~min}$ ) into the medial basal hypothalamus and stalk-median eminence region stimulated GnRH release in a dose-responsive manner in both prepubertal and pubertal ovary-intact female rhesus monkeys. However, when the study was conducted in ovariectomized monkeys, the KP-10-induced stimulation of GnRH release was eliminated in pubertal but not prepubertal monkeys. Furthermore, estradiol add-back to ovariectomized pubertal monkeys resulted in partial recovery of the KP-10-induced GnRH release. Collectively, these results suggest that in the pubertal female monkey, likely at the level of the GnRH neuron, KISS1R responsiveness to $\mathrm{KP}$ is estradiol dependent. The idea that ovarian sex steroids modulate KISS1R responsiveness to KP is further seen in the following study from the Seminara laboratory [121]. There the authors characterized the effects of KP on GnRH secretion in healthy women in different phases of the menstrual cycle by intravenously administering $\mathrm{KP}-10(0.24 \mathrm{nmol} / \mathrm{kg})$ to women in the early follicular phase, the late follicular (preovulatory) phase, and the mid-luteal phase. The results revealed that the response to KP was dependent on the phase of the menstrual cycle where LH pulses were observed immediately after KP administration in all luteal and preovulatory women, but only half of the early follicular phase women exhibited clear KP responses. Like the study conducted in prepubertal and pubertal monkeys [120], in women, KISS1R responsiveness to KP also appears to be estradiol dependent since the early follicular phase is characterized as a period corresponding to low estradiol levels relative to the late follicular (preovulatory) and mid-luteal phases.

While the above studies suggest that estradiol positively regulates KISS1R signaling in the reproductively mature female, in a study by George et al. [122] the authors found that, compared with the early follicular phase, the gonadotropin response to intravenous KP-10 $(0.3 \mu \mathrm{g} / \mathrm{kg})$ is enhanced in sex steroid-deficient postmenopausal women and suppressed in women taking pharmacological doses of exogenous estrogen and progestogen in the form of sex steroid contraceptives. The authors stated that the diminished response to KP-10 in women taking a combined estrogen/progestogen contraceptive is consistent with an inhibitory negative feedback effect of estrogen at the pituitary level [123]. Clearly, further studies are required to better understand how KISS1R signaling is modulated by circulating sex steroid levels, whether such modulation occurs directly or indirectly, and how such modulation might be achieved mechanistically.

\section{An Effective Neuroendocrine System Requires Protection from Rapid Desensitization}

Disruption of the normal amplitude and/or frequency of gonadotropin secretion impacts negatively on fertility as reflected in the high LH pulse frequency in polycystic ovary syndrome and the low LH pulse frequency in hypothalamic amenorrhea. Thus, the neuroendocrine axis has evolved mechanisms that strongly protect against such disruptions. Such mechanisms are evident in the cell biology of the GnRH receptor, which is expressed on anterior pituitary gonadotropes. Gonadotropes maintain an active population of $\mathrm{GnRH}$ receptors at their surface so that the pituitary remains responsive to $\mathrm{GnRH}$ signals at all times. This is proposed to facilitate a protracted LH surge over several hours, an event required for ovulation in mammals 
[46]. The mammalian type I GnRH receptor mediates this by having an evolved resistance to homologous desensitization and internalization through the unique absence of a carboxyl terminal tail among GPCRs, which is required to mediate such events [83, 124-126]. Using radiolabeled $\mathrm{GnRH}$, studies have determined that only about $25 \%$ of the ligand internalizes after $30 \mathrm{~min}$ at $37^{\circ} \mathrm{C}[127,128]$, and while direct measurements of receptor internalization confirmed that GnRH-RI internalized very slowly the constitutive internalization rate was unchanged by the presence of $\mathrm{GnRH}$ where after $90 \mathrm{~min}$ at $37^{\circ} \mathrm{C}$ only about $25 \%$ of the receptor had internalized [46].

In the adult human male, GnRH undergoes pulsatile secretion every $2 \mathrm{~h}$, as interpreted from LH pulsatility [129-139], while in the adult human female, depending on the stage of the menstrual cycle [140-146], GnRH pulsatile release occurs every hour to as long as every $4-6 \mathrm{~h}$ [147]. Pulsatile GnRH secretion therefore seems to have evolved not just to encode specific patterns of gonadotropin secretion but also to safeguard against the desensitization and downregulation of a receptor that once activated remains signaling responsive in a healthy individual for a protracted period. Since the KP/KISS1R signaling system is upstream of $\mathrm{GnRH}$ secretion, it is reasonable to conclude that KISS1R must undergo prolonged signaling to support sustained pulsatile GnRH secretion, a requirement for prolonged GnRH signaling. As discussed previously, through the rapid desensitization, internalization, and recycling of resensitized receptors to the cell surface the cell maintains an active and dynamic population of KISS1R at the cell surface that facilitates prolonged KP signaling. Additionally, it is suggested that in vivo, at the GnRH neuron, by regulating the KP concentration and the duration of exposure of KISS1R to KP, signaling can be further sustained to protect against rapid desensitization of the neuroendocrine axis.

\section{KISS1R: An Effective Clinical Target}

Moving forward, in developing KP-based clinical therapies $[148,149]$ it is crucial to fully understand how to effectively administer native KP and analogs (pulsatile administration vs. chronic administration) to achieve a desired outcome (e.g. prolonged KISS1R signaling and elevated gonadotropins for infertility in contrast to termination of KISS1R signaling and diminished gonadotropin and steroid hormones for the treatment of hormone-dependent diseases). Delineating and understanding the dynamics of KISS1R signaling will assist in designing proto- cols to achieve these stimulatory and inhibitory regimens. This knowledge can then be applied in KP administration under physiological and pathological conditions.

With respect to initiating and prolonging KP signaling, KP must be administered in a manner that ensures pulsatile GnRH secretion that can in turn support the pulsatile gonadotropin secretion needed to maintain fertility. A study conducted on female rhesus monkeys revealed that $\mathrm{KP}$ and $\mathrm{GnRH}$ release in the stalk-median eminence, as assessed by the a microdialysis method, were both pulsatile and had a tendency to occur with similar timing, leading the authors to hypothesize that a pulsatile $\mathrm{GnRH}$ release is associated with pulsatile KP secretion [150]. As every GnRH pulse was not accompanied by a $\mathrm{KP}$ pulse (in contrast to $\mathrm{GnRH}$ pulses which exhibit very close coincidence with LH pulses), more comprehensive studies are required. Nevertheless, there is support for the conclusion that each GnRH pulse is a result of a KP pulse from studies in the goat [5]. These findings suggest that KP may have to be administered in a pulsatile fashion to trigger physiologically appropriate pulsatile gonadotropin secretion. However, as discussed earlier, Millar and colleagues $[105,106]$ found that nonpulsatile continuous administration of $\mathrm{KP}$ was sufficient to induce pulsatile release of $\mathrm{LH}$. This raises the extraordinary and unanticipated possibility that the GnRH neuron can respond to continuous KP by pulsatile release of GnRH. However, as stated earlier, it is expected that KP signaling would eventually desensitize following chronic KP treatment; thus, therapeutic administration of KP aimed at stimulating reproduction, at least over short periods of 1 to a few days, may not require pulsatile administration unlike the therapeutic use of $\mathrm{GnRH}$ which has an absolute requirement for pulsatile delivery.

Based on observations that KP signaling desensitizes following continuous exposure to naturally occurring KPs (table 1), it was immediately apparent that this could be the basis for treating some diseases that require full suppression (e.g. in breast and prostatic cancer therapy) or partial suppression (e.g. in treating endometriosis, polycystic ovarian syndrome, and benign prostatic hyperplasia) of sex steroid levels. However, because the high susceptibility of KP-10 to enzymatic cleavage in vivo and the resulting short half-life [151] limit its potential use as a therapeutic agent, protease-resistant KP agonists that exhibit improved pharmacokinetics and higher affinities than natural ligands have been developed (table 1) [108, 115-118].

Based on their analysis of two of the first KP-10 analogs developed, i.e. KISS1-305 and TAK-448, Matsui et 
al. [108] reported that continuous infusion of the analogs reduced testosterone levels to castrate levels in intact adult male rats within 3 days compared to chronic GnRH agonist (leuprolide) which required 14 days to achieve the same result. In healthy human males, continuous s.c. infusion of another KP analog, i.e. TAK-683 (which has properties similar to those of TAK-448), triggered subcastrate levels of testosterone by day 7 , while in goats s.c. continuous infusion of TAK-683 suppressed LH secretion after as little as 1 day, with marked suppression by day 3 (table 1) $[110,113]$. Because of the remarkable stability of the synthetic agonists in serum, just a single daily s.c. injection of TAK- 448 and TAK-683 was sufficient to achieve desensitization of $\mathrm{LH}$ and testosterone secretion in intact adult male rats by day 4 (table 1) [111]. When TAK-448 was given s.c. to healthy male subjects aged 50 years or older, castrate levels of testosterone were achieved following 8 days of treatment (table 1), and when given as a 1-month depot formulation to prostate cancer patients near-maximum suppression in testosterone levels was achieved by day 10 (table 1) [112].

It is important to note that while the above studies clearly demonstrate the ability to downregulate the neuroendocrine-reproductive axis through chronic exposure to high-affinity and more stable KP agonists, either as continuous infusions or as single daily injections, these studies also clearly reveal that the kinetics of KISS1R desensitization can be modulated by ligand affinity, efficacy, stability, and concentration [108, 110-114]. Therefore, as we continue to develop KP-based therapies, attention must be paid to ligand delivery (continuous vs. pulsatile), efficacy, and concentration.

\section{Conclusion}

This review discussed KISS1R recruitment of intracellular signaling pathways that mediate $\mathrm{GnRH}$ secretion as well as the dynamics of ligand-induced internalization of KISS1R, degradation and recycling, and desensitization/ uncoupling. These deliberations have illustrated that mechanisms have evolved for the cell to potentially prolong KP signaling as has been found for GnRH signaling. Specifically, we described how at the receptor level, by undergoing rapid desensitization, internalization, and continuous recycling of resensitized receptors, coupled to the trafficking of nonrecycling KISS1R to the cell surface, the cell maintains an active and dynamic pool of activatable KISS1R at its surface, resulting in prolonged KP signaling. We also suggest that the KP concentration and the duration of exposure of KISS1R to KP at the GnRH neuron might be regulated to further sustain KP signaling and protect against rapid desensitization of the neuroendocrine axis. As for the type I GnRH receptor, sustained signaling appears necessary to facilitate a protracted $\mathrm{LH}$ surge over several hours, an event required for ovulation in mammals. Studies with KP antagonists $[152,153]$ have indicated that both pulsatile $\mathrm{LH}$ and the $\mathrm{LH}$ surge of ovulation are dependent on KP but the mechanism underlying the shift from pulsatile $\mathrm{LH}$ to the surge is not known [152]. We have also discussed how KISS1R couples to $\beta$-arrestin in addition to coupling to and signaling by $\mathrm{Ga}_{\mathrm{q} / 11}$, and that both pathways mediate KP-dependent GnRH secretion. However, the specific roles of these two signaling pathways have not been resolved and this may be a valuable undertaking for future research. It is plausible that regulation of GnRH secretion by dual KISS1Rmediated signaling provides a means to maintaining some degree of GnRH secretion and fertility should one signaling pathway become inactivated in physiological and pathological scenarios. Finally, we considered how different therapeutic modalities of administration of KP and super active analogs may be used to stimulate or inhibit the reproductive hormone cascade, and how the outcomes may differ from targeting the type I GnRH receptor.

\section{Acknowledgement}

The authors would like to acknowledge the significant contribution to our understanding of the molecular regulation of KISS1R signaling by Dr. Ursula B. Kaiser and her research team at Harvard University, Boston, Mass., USA.

Dr. Babwah's research is supported by the Natural Sciences and Engineering Research Council of Canada (RGPIN/327334-2011). Dr. Millar's research is supported by grants from the National Research Foundation and Medical Research Council of South Africa, and the Universities of Pretoria and Cape Town.

References $\quad D_{1}$ Chan YM, de Guillebon A, Lang-Muritano M, Plummer L, Cerrato F, Tsiaras S, Gaspert A, Lavoie $\mathrm{HB}$, Wu CH, Crowley WF Jr, Amory JK, Pitteloud N, Seminara SB: GnRH1 mutations in patients with idiopathic hypogonadotropic hypogonadism. Proc Natl Acad Sci USA 2009;106:11703-11708.

2 Bianco SD, Kaiser UB: The genetic and molecular basis of idiopathic hypogonadotropic hypogonadism. Nat Rev Endocrinol 2009;5: 569-576. 
-3 de Roux N, Young J, Misrahi M, Genet R, Chanson P, Schaison G, Milgrom E: A family with hypogonadotropic hypogonadism and mutations in the gonadotropin-releasing hormone receptor. N Engl J Med 1997;337:15971602.

-4 Topaloglu AK, Reimann F, Guclu M, Yalin AS, Kotan LD, Porter KM, Serin A, Mungan NO, Cook JR, Ozbek MN, Imamoglu S, Akalin NS, Yuksel B, O'Rahilly S, Semple RK: TAC3 and TACR3 mutations in familial hypogonadotropic hypogonadism reveal a key role for neurokinin $b$ in the central control of reproduction. Nat Genet 2009;41:354-358.

5 Wakabayashi Y, Nakada T, Murata K, Ohkura S, Mogi K, Navarro VM, Clifton DK, Mori Y, Tsukamura H, Maeda K, Steiner RA, Okamura $\mathrm{H}$ : Neurokinin $\mathrm{B}$ and dynorphin $\mathrm{A}$ in kisspeptin neurons of the arcuate nucleus participate in generation of periodic oscillation of neural activity driving pulsatile gonadotropin-releasing hormone secretion in the goat. J Neurosci 2010;30:3124-3132.

-6 Wakabayashi Y, Yamamura T, Sakamoto K, Mori Y, Okamura H: Electrophysiological and morphological evidence for synchronized GnRH pulse generator activity among kisspeptin/neurokinin B/dynorphin A (KNDY) neurons in goats. J Reprod Dev 2013; 59:40-48.

7 Grachev P, Millar RP, O’Byrne KT: The role of neurokinin $\mathrm{B}$ signalling in reproductive neuroendocrinology. Neuroendocrinology 2014;99:7-17.

8 Goodman RL, Coolen LM, Lehman MN: A role for neurokinin B in pulsatile $\mathrm{GnRH}$ secretion in the ewe. Neuroendocrinology 2014; 99:18-32.

9 Hrabovszky E: Neuroanatomy of the human hypothalamic kisspeptin system. Neuroendocrinology 2014;99:33-48.

10 Hrabovszky E, Sipos MT, Molnar CS, Ciofi P, Borsay BA, Gergely P, Herczeg L, Bloom SR, Ghatei MA, Dhillo WS, Liposits Z: Low degree of overlap between kisspeptin, neuroki$\operatorname{nin} \mathrm{B}$, and dynorphin immunoreactivities in the infundibular nucleus of young male human subjects challenges the KNDY neuron concept. Endocrinology 2012;153:49784989.

11 Rometo AM, Krajewski SJ, Voytko ML, Rance NE: Hypertrophy and increased kisspeptin gene expression in the hypothalamic infundibular nucleus of postmenopausal women and ovariectomized monkeys. J Clin Endocrinol Metab 2007;92:2744-2750.

12 Rometo AM, Rance NE: Changes in prodynorphin gene expression and neuronal morphology in the hypothalamus of postmenopausal women. J Neuroendocrinol 2008;20: 1376-1381.

13 Rance NE, Young WS, 3rd: Hypertrophy and increased gene expression of neurons containing neurokinin-B and substance-P messenger ribonucleic acids in the hypothalami of postmenopausal women. Endocrinology 1991;128:2239-2247.
4 de Roux N, Genin E, Carel JC, Matsuda F, Chaussain JL, Milgrom E: Hypogonadotropic hypogonadism due to loss of function of the KISS1-derived peptide receptor GPR54. Proc Natl Acad Sci USA 2003;100:10972-10976.

15 Seminara SB, Messager S, Chatzidaki EE, Thresher RR, Acierno JS, Jr, Shagoury JK, BoAbbas Y, Kuohung W, Schwinof KM, Hendrick AG, Zahn D, Dixon J, Kaiser UB, Slaugenhaupt SA, Gusella JF, O'Rahilly S, Carlton MB, Crowley WF Jr, Aparicio SA, Colledge WH: The GPR54 gene as a regulator of puberty. N ENgl J Med 2003;349:1614-1627.

16 d'Anglemont de Tassigny X, Fagg LA, Dixon JP, Day K, Leitch HG, Hendrick AG, Zahn D, Franceschini I, Caraty A, Carlton MB, Aparicio SA, Colledge WH: Hypogonadotropic hypogonadism in mice lacking a functional Kiss1 gene. Proc Natl Acad Sci USA 2007;104: 10714-10719.

17 Lapatto R, Pallais JC, Zhang D, Chan YM, Mahan A, Cerrato F, Le WW, Hoffman GE, Seminara SB: Kiss1-/- mice exhibit more variable hypogonadism than Gpr54-/- mice. Endocrinology 2007;148:4927-4936.

18 Chan YM, Broder-Fingert S, Paraschos S, Lapatto R, Au M, Hughes V, Bianco SD, Min L, Plummer L, Cerrato F, De Guillebon A, Wu IH, Wahab F, Dwyer A, Kirsch S, Quinton R, Cheetham T, Ozata M, Ten S, Chanoine JP, Pitteloud N, Martin KA, Schiffmann R, Van der Kamp HJ, Nader S, Hall JE, Kaiser UB, Seminara SB: GnRH-deficient phenotypes in humans and mice with heterozygous variants in KISS1/KISS1. J Clin Endocrinol Metab 2011;96:E1771-E1781.

19 Topaloglu AK, Tello JA, Kotan LD, Ozbek MN, Yilmaz MB, Erdogan S, Gurbuz F, Temiz F, Millar RP, Yuksel B: Inactivating KISS1 mutation and hypogonadotropic hypogonadism. N Engl J Med 2012;366:629-635.

20 Kirilov M, Clarkson J, Liu X, Roa J, Campos P, Porteous R, Schutz G, Herbison AE: Dependence of fertility on kisspeptin-GPR54 signaling at the GnRH neuron. Nat Commun 2013;4:2492.

-21 Novaira HJ, Sonko ML, Hoffman G, Koo Y, Ko C, Wolfe A, Radovick S: Disrupted kisspeptin signaling in GnRH neurons leads to hypogonadotrophic hypogonadism. Mol Endocrinol 2014;28:225-238.

22 Ramaswamy S, Seminara SB, Plant TM: Evidence from the agonadal juvenile male rhesus monkey (Macaca mulatta) for the view that the action of neurokinin $\mathrm{B}$ to trigger gonadotropin-releasing hormone release is upstream from the kisspeptin receptor. Neuroendocrinology 2011;94:237-245.

23 Savoy-Moore RT, Swartz KH: Several GnRH stimulation frequencies differentially release FSH and LH from isolated, perfused rat anterior pituitary cells. Adv Exp Med Biol 1987; 219:641-645.

24 Wildt L, Hausler A, Marshall G, Hutchison JS, Plant TM, Belchetz PE, Knobil E: Frequency and amplitude of gonadotropin-releasing hormone stimulation and gonadotropin se- cretion in the rhesus monkey. Endocrinology 1981;109:376-385.

25 Thompson IR, Ciccone NA, Xu S, Zaytseva S, Carroll RS, Kaiser UB: GnRH pulse frequency-dependent stimulation of FSH $\beta$ transcription is mediated via activation of PKA and CREB. Mol Endocrinol 2013;27:606-618.

26 Thompson IR, Kaiser UB: GnRH pulse frequency-dependent differential regulation of LH and FSH gene expression. Mol Cell Endocrinol 2014;385:28-35.

27 Lee DK, Nguyen T, O’Neill GP, Cheng R, Liu Y, Howard AD, Coulombe N, Tan CP, TangNguyen AT, George SR, O'Dowd BF: Discovery of a receptor related to the galanin receptors. FEBS Lett 1999;446:103-107.

28 Clements MK, McDonald TP, Wang R, Xie G, O'Dowd BF, George SR, Austin CP, Liu Q: Fmrfamide-related neuropeptides are agonists of the orphan G-protein-coupled receptor GPR54. Biochem Biophys Res Commun 2001;284:1189-1193.

29 Kotani M, Detheux M, Vandenbogaerde A, Communi D, Vanderwinden JM, Le Poul E, Brezillon S, Tyldesley R, Suarez-Huerta N, Vandeput F, Blanpain C, Schiffmann SN, Vassart G, Parmentier M: The metastasis suppressor gene KISS-1 encodes kisspeptins, the natural ligands of the orphan $\mathrm{G}$ protein-coupled receptor GPR54. J Biol Chem 2001;276: 34631-34636.

30 Muir AI, Chamberlain L, Elshourbagy NA, Michalovich D, Moore DJ, Calamari A, Szekeres PG, Sarau HM, Chambers JK, Murdock P, Steplewski K, Shabon U, Miller JE, Middleton SE, Darker JG, Larminie CG, Wilson S, Bergsma DJ, Emson P, Faull R, Philpott KL, Harrison DC: Axor12, a novel human G protein-coupled receptor, activated by the peptide KISS-1. J Biol Chem 2001;276:2896928975.

- 31 Ohtaki T, Shintani Y, Honda S, Matsumoto H, Hori A, Kanehashi K, Terao Y, Kumano S, Takatsu Y, Masuda Y, Ishibashi Y, Watanabe T, Asada M, Yamada T, Suenaga M, Kitada C, Usuki S, Kurokawa T, Onda H, Nishimura O, Fujino M: Metastasis suppressor gene kiss-1 encodes peptide ligand of a G-protein-coupled receptor. Nature 2001;411:613-617.

-32 Wettschureck N, Offermanns S: Mammalian $\mathrm{G}$ proteins and their cell type specific functions. Physiol Rev 2005;85:1159-1204.

33 Wilkie TM, Scherle PA, Strathmann MP, Slepak VZ, Simon MI: Characterization of Gprotein $\alpha$ subunits in the Gq class: expression in murine tissues and in stromal and hematopoietic cell lines. Proc Natl Acad Sci USA 1991;88:10049-10053.

34 Allen Institute for Brain Science: Allen Brain Atlas. http://www.brain-map.org/

35 Wacker JL, Feller DB, Tang XB, Defino MC, Namkung Y, Lyssand JS, Mhyre AJ, Tan X, Jensen JB, Hague C: Disease-causing mutation in GPR54 reveals the importance of the second intracellular loop for class a G-protein-coupled receptor function. J Biol Chem 2008;283:31068-31078. 
36 Offermanns S, Simon MI: Ga 15 and Ga 16 couple a wide variety of receptors to phospholipase C. J Biol Chem 1995;270:15175-15180.

- 37 Offermanns S, Negulescu P, Hu YH, Simon MI: Conditionally expressed $\mathrm{G} \alpha 15$ couples to endogenous receptors in GH3 cells. Naunyn Schmiedebergs Arch Pharmacol 2001;364: 140-148.

- 38 Ho MK, Yung LY, Chan JS, Chan JH, Wong $\mathrm{CS}$, Wong $\mathrm{YH}: \mathrm{Ga}(14)$ links a variety of $\mathrm{Ga}(\mathrm{i})$ and $\mathrm{Ga}(\mathrm{s})$-coupled receptors to the stimulation of phospholipase C. Br J Pharmacol 2001; 132:1431-1440.

39 Venkatachalam K, Montell C: TRP channels Annu Rev Biochem 2007;76:387-417.

40 Liu X, Lee K, Herbison AE: Kisspeptin excites gonadotropin-releasing hormone neurons through a phospholipase $\mathrm{C} /$ calcium-dependent pathway regulating multiple ion channels. Endocrinology 2008;149:4605-4614.

41 Pielecka-Fortuna J, Chu Z, Moenter SM: Kisspeptin acts directly and indirectly to increase gonadotropin-releasing hormone neuron activity and its effects are modulated by estradiol. Endocrinology 2008;149:1979-1986.

-42 Constantin S, Caligioni CS, Stojilkovic S, Wray S: Kisspeptin-10 facilitates a plasma membrane-driven calcium oscillator in gonadotropin-releasing hormone-1 neurons. Endocrinology 2009;150:1400-1412.

-43 Kroll H, Bolsover S, Hsu J, Kim SH, Bouloux PM: Kisspeptin-evoked calcium signals in isolated primary rat gonadotropin- releasing hormone neurones. Neuroendocrinology 2011;93:114-120.

-44 Zhang C, Bosch MA, Ronnekleiv OK, Kelly MJ: Kisspeptin activation of TRPC4 channels in female GnRH neurons requires PIP2 depletion and cSrc kinase activation. Endocrinology 2013;154:2772-2783.

45 Pampillo M, Camuso N, Taylor JE, Szereszewski JM, Ahow MR, Zajac M, Millar RP, Bhattacharya M, Babwah AV: Regulation of GRP54 signaling by GRK2 and $\beta$-arrestin. Mol Endocrinol 2009;23:2060-2074

-46 Pawson AJ, Faccenda E, Maudsley S, Lu ZL, Naor Z, Millar RP: Mammalian type I gonadotropin-releasing hormone receptors undergo slow, constitutive, agonist-independent internalization. Endocrinology 2008;149:1415-1422.

-47 Sallese M, Salvatore L, D’Urbano E, Sala G, Storto M, Launey T, Nicoletti F, Knopfel T, De Blasi A: The G-protein-coupled receptor kinase GRK4 mediates homologous desensitization of metabotropic glutamate receptor 1. FASEB J 2000;14:2569-2580.

48 Fourgeaud L, Bessis AS, Rossignol F, Pin JP, Olivo-Marin JC, Hemar A: The metabotropic glutamate receptor mGluR5 is endocytosed by a clathrin-independent pathway. J Biol Chem 2003;278:12222-12230.

49 Bhattacharya M, Babwah AV, Godin C, Anborgh PH, Dale LB, Poulter MO, Ferguson SS: Ral and phospholipase D2-dependent pathway for constitutive metabotropic glutamate receptor endocytosis. J Neurosci 2004;24: 8752-8761.
50 Pula G, Mundell SJ, Roberts PJ, Kelly E: Agonist-independent internalization of metabotropic glutamate receptor $1 \mathrm{a}$ is arrestin- and clathrin-dependent and is suppressed by receptor inverse agonists. J Neurosci 2004;89: 1009-1020.

51 Min L, Soltis K, Reis AC, Xu S, Kuohung W, Jain M, Carroll RS, Kaiser UB: Dynamic kisspeptin receptor trafficking modulates kisspeptin-mediated calcium signaling. Mol Endocrinol 2014;28:16-27.

52 Elhabazi K, Humbert JP, Bertin I, Schmitt M, Bihel F, Bourguignon JJ, Bucher B, Becker JA, Sorg T, Meziane H, Petit-Demouliere B, Ilien B, Simonin F: Endogenous mammalian RF-amide peptides, including PrRP, kisspeptin and 26RFa, modulate nociception and morphine analgesia via NPFF receptors. Neuropharmacology 2013;75:164171

53 Seminara SB, Hayes FJ, Crowley WF Jr: Gonadotropin-releasing hormone deficiency in the human (idiopathic hypogonadotropic hypogonadism and Kallmann's syndrome): pathophysiological and genetic considerations. Endocr Rev 1998;19:521-539.

54 Hadziselimovic F, Zivkovic D, Bica DT, Emmons LR: The importance of mini-puberty for fertility in cryptorchidism. J Urol 2005; 174:1536-1539.

55 Nishio H, Mizuno K, Moritoki Y, Kamisawa H, Kojima Y, Mizuno H, Kohri K, Hayashi Y: Clinical features and testicular morphology in patients with Kallmann syndrome. Urology 2012;79:684-686

56 Boyar RM, Rosenfeld RS, Kapen S, Finkelstein JW, Roffwarg HP, Weitzman ED, Hellman L: Human puberty: simultaneous augmented secretion of luteinizing hormone and testosterone during sleep. J Clin Invest 1974;54: 609-618.

57 Jakacki RI, Kelch RP, Sauder SE, Lloyd JS, Hopwood NJ, Marshall JC: Pulsatile secretion of luteinizing hormone in children. J Clin Endocrinol Metab 1982;55:453-458.

8 Wennink JM, Delemarre-van de Waal HA, van Kessel H, Mulder GH, Foster JP, Schoemaker J: Luteinizing hormone secretion patterns in boys at the onset of puberty measured using a highly sensitive immunoradiometric assay. J Clin Endocrinol Metab 1988;67:924928.

59 Wu FC, Butler GE, Kelnar CJ, Sellar RE: Patterns of pulsatile luteinizing hormone secretion before and during the onset of puberty in boys: a study using an immunoradiometric assay. J Clin Endocrinol Metab 1990;70:629637.

60 Bridges NA, Matthews DR, Hindmarsh PC, Brook CG: Changes in gonadotrophin secretion during childhood and puberty. J Endocrinol 1994;141:169-176.

61 Wu FC, Butler GE, Kelnar CJ, Huhtaniemi I, Veldhuis JD: Ontogeny of pulsatile gonadotropin releasing hormone secretion from midchildhood, through puberty, to adulthood in the human male: a study using decon- volution analysis and an ultrasensitive immunofluorometric assay. J Clin Endocrinol Metab 1996;81:1798-1805.

62 Iddon CA, Charlton HM, Fink G: Gonadotrophin release in hypogonadal and normal mice after electrical stimulation of the median eminence or injection of luteinizing hormone releasing hormone. J Endocrinol 1980;85:105110

63 Suter KJ, Pohl CR, Plant TM: The pattern and tempo of the pubertal reaugmentation of open-loop pulsatile gonadotropin-releasing hormone release assessed indirectly in the male rhesus monkey (Macaca mulatta). Endocrinology 1998;139:2774-2783.

64 Shahab M, Mastronardi C, Seminara SB Crowley WF, Ojeda SR, Plant TM: Increased hypothalamic GPR54 signaling: a potential mechanism for initiation of puberty in primates. Proc Natl Acad Sci USA 2005;102: 2129-2134.

65 Gay VL, Plant TM: Sustained intermittent release of gonadotropin-releasing hormone in the prepubertal male rhesus monkey induced by N-methyl-DL-aspartic acid. Neuroendocrinology 1988;48:147-152.

-66 Shahab M, Balasubramaniam A, Sahu A, Plant TM: Central nervous system receptors involved in mediating the inhibitory action of neuropeptide $\mathrm{Y}$ on luteinizing hormone secretion in the male rhesus monkey (Macaca mulatta). J Neuroendocrinol 2003;15:965970

67 Ramaswamy S, Pohl CR, McNeilly AS, Winters SJ, Plant TM: The time course of folliclestimulating hormone suppression by recombinant human inhibin $\mathrm{A}$ in the adult male rhesus monkey (Macaca mulatta). Endocrinology 1998;139:3409-3415.

68 Seminara SB, Dipietro MJ, Ramaswamy S, Crowley WF Jr, Plant TM: Continuous human metastin 45-54 infusion desensitizes G protein-coupled receptor 54 -induced gonadotropin-releasing hormone release monitored indirectly in the juvenile male rhesus monkey (Macaca mulatta): a finding with therapeutic implications. Endocrinology 2006;147:2122-2126

69 Crowley WF Jr, Beitins IZ, Vale W, Kliman B, Rivier J, Rivier C, McArthur JW: The biologic activity of a potent analogue of gonadotropinreleasing hormone in normal and hypogonadotropic men. N Engl J Med 1980;302: 1052-1057.

70 Zimmer CA, Ehrmann DA, Rosenfield RL Potential diagnostic utility of intermittent administration of short-acting gonadotropin-releasing hormone agonist in gonadotropin deficiency. Fertil Steril 2010;94:26972702.

-71 Sykiotis GP, Hoang XH, Avbelj M, Hayes FJ Thambundit A, Dwyer A, Au M, Plummer L, Crowley WF Jr, Pitteloud N: Congenital idiopathic hypogonadotropic hypogonadism: evidence of defects in the hypothalamus, pituitary, and testes. J Clin Endocrinol Metab 2010;95:3019-3027. 
72 Aiyer MS, Chiappa SA, Fink G: A priming effect of luteinizing hormone releasing factor on the anterior pituitary gland in the female rat. J Endocrinol 1974;62:573-588.

-73 Sollenberger MJ, Carlsen EC, Booth RA Jr, Johnson ML, Veldhuis JD, Evans WS: Nature of gonadotropin-releasing hormone selfpriming of luteinizing hormone secretion during the normal menstrual cycle. Am J Obstet Gynecol 1990;163:1529-1534.

74 Crawford JL, McNeilly JR, McNeilly AS: No evidence for pituitary priming to gonadotropin-releasing hormone in relation to luteinizing hormone $(\mathrm{LH})$ secretion prior to the preovulatory LH surge in ewes. Biol Reprod 2004;71:224-235.

75 Luttrell LM, Lefkowitz RJ: The role of $\beta$-arrestins in the termination and transduction of G-protein-coupled receptor signals. J Cell Sci 2002;115:455-465.

-76 DeWire SM, Ahn S, Lefkowitz RJ, Shenoy SK: $\beta$-Arrestins and cell signaling. Annu Rev Physiol 2007;69:483-510.

77 Defea K: $\beta$-Arrestins and heterotrimeric Gproteins: collaborators and competitors in signal transduction. Br J Pharmacol 2008; 153(suppl 1):S298-309.

-78 Kovacs JJ, Hara MR, Davenport CL, Kim J, Lefkowitz RJ: Arrestin development: emerging roles for $\beta$-arrestins in developmental signaling pathways. Dev Cell 2009;17:443-458.

79 Shukla AK, Xiao K, Lefkowitz RJ: Emerging paradigms of $\beta$-arrestin-dependent seven transmembrane receptor signaling. Trends Biochem Sci 2011;36:457-469.

80 Szereszewski JM, Pampillo M, Ahow MR, Offermanns S, Bhattacharya M, Babwah AV: GPR54 regulates ERK1/2 activity and hypothalamic gene expression in a $\mathrm{Ga}(\mathrm{q} / 11)$ and $\beta$-arrestin-dependent manner. PLoS One 2010;5:e12964.

-81 Ahow M, Min L, Pampillo M, Nash C, Wen J, Soltis K, Carroll RS, Glidewell-Kenney CA, Mellon PL, Bhattacharya M, Tobet SA, Kaiser UB, Babwah AV: KISS1R signals independently of $\mathrm{Ga}(\mathrm{q} / 11)$ and triggers LH secretion via the $\beta$-arrestin pathway in the male mouse. Endocrinology 2014;155:4433-4446.

-82 Vrecl M, Anderson L, Hanyaloglu A, McGregor AM, Groarke AD, Milligan G, Taylor PL, Eidne KA: Agonist-induced endocytosis and recycling of the gonadotropin-releasing hormone receptor: effect of $\beta$-arrestin on internalization kinetics. Mol Endocrinol 1998; 12:1818-1829.

83 McArdle CA, Davidson JS, Willars GB: The tail of the gonadotrophin-releasing hormone receptor: desensitization at, and distal to, G protein-coupled receptors. Mol Cell Endocrinol 1999;151:129-136.

-84 Heding A, Vrecl M, Hanyaloglu AC, Sellar R, Taylor PL, Eidne KA: The rat gonadotropinreleasing hormone receptor internalizes via a $\beta$-arrestin-independent, but dynamin-dependent, pathway: addition of a carboxyl-terminal tail confers beta-arrestin dependency. Endocrinology 2000;141:299-306.
85 Hislop JN, Everest HM, Flynn A, Harding T, Uney JB, Troskie BE, Millar RP, McArdle CA Differential internalization of mammalian and non-mammalian gonadotropin-releasing hormone receptors: uncoupling of dynamin-dependent internalization from mitogen-activated protein kinase signaling. J Biol Chem 2001;276:39685-39694.

86 Dhami GK, Babwah AV, Sterne-Marr R, Ferguson SS: Phosphorylation-independent regulation of metabotropic glutamate receptor 1 signaling requires $\mathrm{G}$ protein-coupled receptor kinase 2 binding to the second intracellular loop. J Biol Chem 2005;280:2442024427.

87 Dhami GK, Dale LB, Anborgh PH, O'ConnorHalligan KE, Sterne-Marr R, Ferguson SS: G protein-coupled receptor kinase 2 regulator of $G$ protein signaling homology domain binds to both metabotropic glutamate receptor 1a and Galphaq to attenuate signaling. J Biol Chem 2004;279:16614-16620.

-88 Lorenz S, Frenzel R, Paschke R, Breitwieser GE, Miedlich SU: Functional desensitization of the extracellular calcium-sensing receptor is regulated via distinct mechanisms: role of $\mathrm{G}$ protein-coupled receptor kinases, protein kinase $C$ and $\beta$-arrestins. Endocrinology 2007; 148:2398-2404.

89 Oakley RH, Laporte SA, Holt JA, Barak LS, Caron MG: Association of beta-arrestin with $G$ protein-coupled receptors during clathrinmediated endocytosis dictates the profile of receptor resensitization. J Biol Chem 1999; 274:32248-32257.

90 Bianco SD, Vandepas L, Correa-Medina M, Gereben B, Mukherjee A, Kuohung W, Carroll R, Teles MG, Latronico AC, Kaiser UB: KISS1R intracellular trafficking and degradation: effect of the Arg386Pro disease-associated mutation. Endocrinology 2011;152:16161626.

91 Chretien L, Laporte SA, Escher E, Leduc R, Guillemette G: Use of $\mathrm{LiCl}$ in phospholipase $\mathrm{C}$ assays masks the impaired functionality of a mutant angiotensin II receptor. Cell Signal 1997;9:379-382.

-92 Oakley RH, Laporte SA, Holt JA, Caron MG, Barak LS: Differential affinities of visual arrestin, $\beta$ arrestin 1 , and $\beta$ arrestin 2 for $G$ protein-coupled receptors delineate two major classes of receptors. J Biol Chem 2000;275: 17201-17210.

93 Re M, Pampillo M, Savard M, Dubuc C, McArdle CA, Millar RP, Conn PM, Gobeil F Jr, Bhattacharya M, Babwah AV: The human gonadotropin releasing hormone type I receptor is a functional intracellular GPCR expressed on the nuclear membrane. PLoS One 2010;5:e11489.

4 Kern A, Agoulnik AI, Bryant-Greenwood GD: The low-density lipoprotein class a module of the relaxin receptor (leucine-rich repeat containing G-protein coupled receptor 7): its role in signaling and trafficking to the cell membrane. Endocrinology 2007;148:11811194.
$\$ 95$ Kern A, Bryant-Greenwood GD: Characterization of relaxin receptor (RXFP1) desensitization and internalization in primary human decidual cells and RXFP1-transfected HEK293 cells. Endocrinology 2009; 150: 2419-2428.

-96 Babwah AV, Pampillo M, Min L, Kaiser UB, Bhattacharya M: Single-cell analyses reveal that KISS1R-expressing cells undergo sustained kisspeptin-induced signaling that is dependent upon an influx of extracellular $\mathrm{Ca}^{2+}$. Endocrinology 2012;153: 5875-5887.

$\$ 97$ Mellon PL, Windle JJ, Goldsmith PC, Padula CA, Roberts JL, Weiner RI: Immortalization of hypothalamic GnRH neurons by genetically targeted tumorigenesis. Neuron 1990;5:1-10.

98 Feng X, Zhang J, Barak LS, Meyer T, Caron MG, Hannun YA: Visualization of dynamic trafficking of a protein kinase C $\beta \mathrm{II} /$ green fluorescent protein conjugate reveals differences in $\mathrm{G}$ protein-coupled receptor activation and desensitization. J Biol Chem 1998; 273:10755-10762.

-99 Thompson EL, Murphy KG, Patterson M, Bewick GA, Stamp GW, Curtis AE, Cooke JH, Jethwa PH, Todd JF, Ghatei MA, Bloom SR: Chronic subcutaneous administration of kisspeptin-54 causes testicular degeneration in adult male rats. Am J Physiol Endocrinol Metab 2006;291:E1074-E1082.

100 Messager S, Chatzidaki EE, Ma D, Hendrick AG, Zahn D, Dixon J, Thresher RR, Malinge I, Lomet D, Carlton MB, Colledge $\mathrm{WH}$, Caraty A, Aparicio SA: Kisspeptin directly stimulates gonadotropin-releasing hormone release via $G$ protein-coupled receptor 54. Proc Natl Acad Sci USA 2005; 102:17611766.

101 Tovar S, Vazquez MJ, Navarro VM, Fernandez-Fernandez R, Castellano JM, Vigo E, Roa J, Casanueva FF, Aguilar E, Pinilla L, Dieguez C, Tena-Sempere M: Effects of single or repeated intravenous administration of kisspeptin upon dynamic LH secretion in conscious male rats. Endocrinology 2006; 147:2696-2704.

102 Ramaswamy S, Seminara SB, Pohl CR, DiPietro MJ, Crowley WF Jr, Plant TM: Effect of continuous intravenous administration of human metastin 45-54 on the neuroendocrine activity of the hypothalamic-pituitary-testicular axis in the adult male rhesus monkey (Macaca mulatta). Endocrinology 2007;148:3364-3370.

103 Roa J, Vigo E, Garcia-Galiano D, Castellano JM, Navarro VM, Pineda R, Dieguez C, Aguilar E, Pinilla L, Tena-Sempere M: Desensitization of gonadotropin responses to kisspeptin in the female rat: analyses of LH and FSH secretion at different developmental and metabolic states. Am J Physiol Endocrinol Metab 2008; 294:E1088-E1096. 
-104 Jayasena CN, Nijher GM, Chaudhri OB, Murphy KG, Ranger A, Lim A, Patel D, Mehta A, Todd C, Ramachandran R, Salem V, Stamp GW, Donaldson M, Ghatei MA, Bloom SR, Dhillo WS: Subcutaneous injection of kisspeptin-54 acutely stimulates gonadotropin secretion in women with hypothalamic amenorrhea, but chronic administration causes tachyphylaxis. J Clin Endocrinol Metab 2009;94:4315-4323.

105 George JT, Veldhuis JD, Roseweir AK, Newton CL, Faccenda E, Millar RP, Anderson RA: Kisspeptin-10 is a potent stimulator of $\mathrm{LH}$ and increases pulse frequency in men. J Clin Endocrinol Metab 2011;96:E1228E1236.

106 Young J, George JT, Tello JA, Francou B, Bouligand J, Guiochon-Mantel A, BraillyTabard S, Anderson RA, Millar RP: Kisspeptin restores pulsatile $\mathrm{LH}$ secretion in patients with neurokinin B signaling deficiencies: physiological, pathophysiological and therapeutic implications. Neuroendocrinology 2013;97:193-202.

107 d'Anglemont de Tassigny X, Fagg LA, Carlton MB, Colledge WH: Kisspeptin can stimulate gonadotropin-releasing hormone $(\mathrm{GnRH})$ release by a direct action at $\mathrm{GnRH}$ nerve terminals. Endocrinology 2008; 149: 3926-3932.

108 Matsui H, Tanaka A, Yokoyama K, Takatsu Y, Ishikawa K, Asami T, Nishizawa N, Suzuki A, Kumano S, Terada M, Kusaka M, Kitada C, Ohtaki T: Chronic administration of the metastin/kisspeptin analog KISS1305 or the investigational agent TAK-448 suppresses hypothalamic pituitary gonadal function and depletes plasma testosterone in adult male rats. Endocrinology 2012;153: 5297-5308.

109 Yamamura T, Wakabayashi Y, Sakamoto K, Matsui H, Kusaka M, Tanaka T, Ohkura S, Okamura H: The effects of chronic subcutaneous administration of an investigational kisspeptin analog, TAK-683, on gonadotropin-releasing hormone pulse generator activity in goats. Neuroendocrinology 2014; 100:250-264.

110 Scott G, Ahmad I, Howard K, MacLean D, Oliva C, Warrington S, Wilbraham D, Worthington P: Double-blind, randomized, placebo-controlled study of safety, tolerability, pharmacokinetics and pharmacodynamics of TAK-683, an investigational metastin analogue in healthy men. Br J Clin Pharmacol 2013;75:381-391.

111 Matsui H, Masaki T, Akinaga Y, Kiba A, Takatsu Y, Nakata D, Tanaka A, Ban J, Matsumoto S, Kumano S, Suzuki A, Ikeda Y, Yamaguchi M, Watanabe T, Ohtaki T, Kusaka M: Pharmacologic profiles of investigational kisspeptin/metastin analogues, TAK-448 and TAK-683, in adult male rats in comparison to the GnRH analogue leuprolide. Eur J Pharmacol 2014;735:77-85.

112 MacLean DB, Matsui H, Suri A, Neuwirth R, Colombel M: Sustained exposure to the in- vestigational kisspeptin analog, TAK-448, down-regulates testosterone into the castration range in healthy males and in patients with prostate cancer: results from two phase 1 studies. J Clin Endocrinol Metab 2014; 99:E1445-E1453.

113 Yamamura T, Wakabayashi Y, Sakamoto K, Matsui H, Kusaka M, Tanaka T, Ohkura S, Okamura H: The effects of chronic subcutaneous administration of an investigational kisspeptin analog, TAK-683, on gonadotropin-releasing hormone pulse generator activity in goats. Neuroendocrinology 2014; 100:250-264.

114 Lowe JD, Bailey CP: Functional selectivity and time-dependence of $\mu$-opioid receptor desensitization at nerve terminals in the mouse ventral tegmental area. Br J Pharmacol 2015; 172:469-481.

115 Asami T, Nishizawa N, Matsui H, Ishibashi Y, Nishibori K, Horikoshi Y, Nakayama M, Matsumoto S, Tarui N, Yamaguchi M, Matsumoto H, Ohtaki T, Kitada C: Synthesis and biological evaluation of a novel nonapeptide KISS1R agonist with testosteronesuppressive activity (abstract P131-116). Proc 5th Int Pept Symp Program, Kyoto, 2010, p 132.

116 Asami T, Nishozawa N: Metastin derivatives and use thereof. Patent No US7, 960:348. 2007.

117 Kitada C, Asami T, Nishizawa N: Metastin derivatives and use thereof. Patent No US7, 625:869. 2006.

118 Matsui H, Takatsu Y, Tanaka A, Asami T, Nishizawa N, Kiba A, Kumano S, Suzuki A, Kusaka M, Ohtaki T: Potent and efficient testosterone suppression by chronic administration of novel metastin analogues, TAK448 and TAK-683, in male rats. 21st Meet Eur Assoc Cancer Res, Oslo, 2010, p 66.

-119 George JT, Veldhuis JD, Tena-Sempere M, Millar RP, Anderson RA: Exploring the pathophysiology of hypogonadism in men with type 2 diabetes: kisspeptin-10 stimulates serum testosterone and $\mathrm{LH}$ secretion in men with type 2 diabetes and mild biochemical hypogonadism. Clin Endocrinol 2013; 79:100-104.

120 Guerriero KA, Keen KL, Millar RP, Terasawa E: Developmental changes in GnRH release in response to kisspeptin agonist and antagonist in female rhesus monkeys ( $\mathrm{Ma}$ caca mulatta): implication for the mechanism of puberty. Endocrinology 2012;153: 825-836.

121 Chan YM, Butler JP, Sidhoum VF, Pinnell NE, Seminara SB: Kisspeptin administration to women: a window into endogenous kisspeptin secretion and GnRH responsiveness across the menstrual cycle. J Clin Endocrinol Metab 2012;97:E1458-E1467.

122 George JT, Anderson RA, Millar RP: Kisspeptin-10 stimulation of gonadotrophin secretion in women is modulated by sex steroid feedback. Hum Reprod 2012;27:35523559.
123 Shaw ND, Histed SN, Srouji SS, Yang J, Lee $\mathrm{H}$, Hall JE: Estrogen negative feedback on gonadotropin secretion: evidence for a direct pituitary effect in women. J Clin Endocrinol Metab 2010;95:1955-1961.

124 Kakar SS, Musgrove LC, Devor DC, Sellers JC, Neill JD: Cloning, sequencing, and expression of human gonadotropin releasing hormone $(\mathrm{GnRH})$ receptor. Biochem Biophys Res Commun 1992;189:289-295.

125 Janovick JA, Ulloa-Aguirre A, Conn PM: Evolved regulation of gonadotropin-releasing hormone receptor cell surface expression. Endocrine 2003;22:317-327.

126 Pawson AJ, Katz A, Sun YM, Lopes J, Illing N, Millar RP, Davidson JS: Contrasting internalization kinetics of human and chicken gonadotropin-releasing hormone receptors mediated by C-terminal tail. J Endocrinol 1998;156:R9-R12.

127 Millar RP, Lu ZL, Pawson AJ, Flanagan CA, Morgan K, Maudsley SR: Gonadotropin-releasing hormone receptors. Endocr Rev 2004;25:235-275.

128 Pawson AJ, McNeilly AS: The pituitary effects of GnRH. Anim Reprod Sci 2005;88: 75-94.

129 Nankin HR, Troen P: Repetitive luteinizing hormone elevations in serum of normal men. J Clin Endocrinol Metab 1971;33:558560.

130 Nankin HR, Troen P: Overnight patterns of serum luteinizing hormone in normal men. J Clin Endocrinol Metab 1972;35: 705-710.

131 Boyar R, Perlow M, Hellman L, Kapen S, Weitzman E: Twenty-four hour pattern of luteinizing hormone secretion in normal men with sleep stage recording. J Clin Endocrinol Metab 1972;35:73-81.

132 Naftolin F, Yen SS, Tsai CC: Rapid cycling of plasma gonadotrophins in normal men as demonstrated by frequent sampling. Nat New Biol 1972;236:92-93.

133 McNeilly AS, Sturdy J, Evans DG, Chard T: Short-term variation in blood levels of prolactin, luteinizing hormone and folliclestimulating hormone in normal men throughout the day. J Endocrinol 1974;61: 301-302.

134 Santen RJ, Bardin CW: Episodic luteinizing hormone secretion in man: pulse analysis, clinical interpretation, physiologic mechanisms. J Clin Invest 1973;52:2617-2628.

135 Baker HW, Santen RJ, Burger HG, De Kretser DM, Hudson B, Pepperell RJ, Bardin CW: Rhythms in the secretion of gonadotropins and gonadal steroids. J Steroid Biochem 1975;6:793-801.

136 Winters SJ, Troen P: A reexamination of pulsatile luteinizing hormone secretion in primary testicular failure. J Clin Endocrinol Metab 1983;57:432-435.

137 Matsumoto AM, Bremner WJ: Modulation of pulsatile gonadotropin secretion by testosterone in man. J Clin Endocrinol Metab 1984;58:609-614. 
138 Veldhuis JD, Evans WS, Johnson ML, Wills MR, Rogol AD: Physiological properties of the luteinizing hormone pulse signal: impact of intensive and extended venous sampling paradigms on its characterization in healthy men and women. J Clin Endocrinol Metab 1986;62:881-891.

139 Spratt DI, O’Dea LS, Schoenfeld D, Butler J, Rao PN, Crowley WF Jr: Neuroendocrinegonadal axis in men: frequent sampling of $\mathrm{LH}, \mathrm{FSH}$, and testosterone. Am J Physiol 1988;254:E658-E666.

140 Santoro N, Filicori M, Crowley WF Jr: Hypogonadotropic disorders in men and women: diagnosis and therapy with pulsatile gonadotropin-releasing hormone. Endocr Rev 1986;7:11-23.

-141 Yen SS, Tsai CC, Naftolin F, Vandenberg G, Ajabor L: Pulsatile patterns of gonadotropin release in subjects with and without ovarian function. J Clin Endocrinol Metab 1972;34: 671-675.

142 Backstrom CT, McNeilly AS, Leask RM, Baird DT: Pulsatile secretion of LH, FSH, prolactin, oestradiol and progesterone during the human menstrual cycle. Clin Endocrinol 1982;17:29-42.

143 Reame N, Sauder SE, Kelch RP, Marshall JC: Pulsatile gonadotropin secretion during the human menstrual cycle: evidence for altered frequency of gonadotropin-releasing hormone secretion. J Clin Endocrinol Metab 1984;59:328-337.
144 Filicori M, Butler JP, Crowley WF Jr: Neuroendocrine regulation of the corpus luteum in the human: evidence for pulsatile progesterone secretion. J Clin Invest 1984;73:16381647.

145 Soules MR, Steiner RA, Cohen NL, Bremner WJ, Clifton DK: Nocturnal slowing of pulsatile luteinizing hormone secretion in women during the follicular phase of the menstrual cycle. J Clin Endocrinol Metab 1985;61:4349.

146 Evans WS, Sollenberger MJ, Booth RA Jr, Rogol AD, Urban RJ, Carlsen EC, Johnson ML, Veldhuis JD: Contemporary aspects of discrete peak-detection algorithms. 2. The paradigm of the luteinizing hormone pulse signal in women. Endocr Rev 1992;13:81104.

147 Hall JE, Schoenfeld DA, Martin KA, Crowley WF Jr: Hypothalamic gonadotropin-releasing hormone secretion and follicle-stimulating hormone dynamics during the luteal-follicular transition. J Clin Endocrinol Metab 1992;74:600-607.

148 Roseweir AK, Millar RP: Kisspeptin antagonists. Adv Exp Med Biol 2013;784:159-186.

149 Millar RP, Roseweir AK, Tello JA, Anderson RA, George JT, Morgan K, Pawson AJ: Kisspeptin antagonists: unraveling the role of kisspeptin in reproductive physiology. Brain Res 2010;1364:81-89.
150 Keen KL, Wegner FH, Bloom SR, Ghatei MA, Terasawa E: An increase in kisspeptin-54 release occurs with the pubertal increase in luteinizing hormone-releasing hormone-1 release in the stalk-median eminence of female rhesus monkeys in vivo. Endocrinology 2008;149:4151-4157.

151 Liu Z, Ren C, Jones W, Chen P, Seminara SB, Chan YM, Smith NF, Covey JM, Wang J, Chan KK: LC-MS/MS quantification of a neuropeptide fragment kisspeptin-10 (NSC 741805) and characterization of its decomposition product and pharmacokinetics in rats. J Chromatorg B Analyt Technol Biomed Life Sci 2013;926:1-8.

152 Roseweir AK, Kauffman AS, Smith JT, Guerriero KA, Morgan K, Pielecka-Fortuna J, Pineda R, Gottsch ML, Tena-Sempere M, Moenter SM, Terasawa E, Clarke IJ, Steiner RA, Millar RP: Discovery of potent kisspeptin antagonists delineate physiological mechanisms of gonadotropin regulation. J Neurosci 2009;29:3920-3929.

153 Pineda R, Garcia-Galiano D, Roseweir A, Romero M, Sanchez-Garrido MA, RuizPino F, Morgan K, Pinilla L, Millar RP, Tena-Sempere M: Critical roles of kisspeptins in female puberty and preovulatory gonadotropin surges as revealed by a novel antagonist. Endocrinology 2010;151:722730. 